\title{
Core or periphery? The effects of country-of- origin agglomerations on the within-country expansion of MNEs
}

\author{
Maximilian Stallkamp ${ }^{1}$, \\ Brian C Pinkham ${ }^{1}$, \\ Andreas P J Schotter ${ }^{1}$ \\ and Olha Buchel ${ }^{2}$
}

\footnotetext{
${ }^{1}$ Ivey Business School, Western University, 1255 Western Road, London, ON N6G 0N1, Canada;

${ }^{2}$ Si Technology Group, Inc., London, ON, Canada

\section{Correspondence:}

APJ Schotter, Ivey Business School, Western University, 1255 Western Road, London, ON N6G 0N1, Canada.

Tel: +1-519-661-3038;

e-mail: aschotter@ivey.ca
}

\begin{abstract}
We show how the initial subnational entry location of foreign multinational enterprises (MNEs) in China influences their subsequent within-country location choices and expansion speed. We distinguish between MNEs that establish their first subsidiary in co-ethnic cores - dense agglomerations of other firms from the same country of origin - and MNEs that locate their first subsidiary in the periphery, i.e., outside of these co-ethnic cores. To identify co-ethnic cores in China, we employ a geo-visualization methodology, which draws the boundaries of cores organically and dynamically over time. We contrast our findings with the prevailing approach of using static administrative boundaries for identifying agglomerations. Our results provide evidence of path dependency, in that (a) entry through subnational locations with strong co-ethnic communities is followed by expansion into other locations where co-ethnic communities are present, and that (b) entry through co-ethnic communities accelerates the pace at which MNEs establish additional subsidiaries in China. We also find that co-ethnic community effects continue to influence within-country MNE activities over time, despite a host of economic, institutional, and investment developments.
\end{abstract}

Journal of International Business Studies (2018) 49, 942-966.

https://doi.org/| 0.1057/s4|267-0|6-0060-x

Keywords: FDI agglomeration; MNE subnational expansion; co-ethnic FDI; geo-visualization; core-periphery framework

The online version of this article is available Open Access

\section{INTRODUCTION}

There is growing interest among international business (IB) scholars in the characteristics and effects of foreign multinational enterprise (MNE) agglomerations, including those based on a shared country of origin (Kim, 2015; Tan \& Meyer, 2011; Zhu, Eden, Miller, Thomas, \& Fields, 2012). Although the extant literature suggests that these types of agglomerations appear attractive as locations for MNEs' first entry in a new host country (Henisz \& Delios, 2001; Tan \& Meyer, 2011; Zhu et al., 2012), we do not yet know how these entry locations shape the subsequent geographic expansion of MNEs within the host country.

MNE agglomeration research can be divided into two streams. ${ }^{1}$ One stream investigates MNE-to-MNE linkages based on industry- or activity-based clusters, MNE capabilities, and MNE strategy 
(Beugelsdijk \& Mudambi, 2013; Cano-Kollmann, Cantwell, Hannigan, Mudambi, \& Song, 2016; Klier \& McMillen, 2008a, b; Mariotti, Piscitello, \& Elia, 2010; Porter, 1998). A second stream investigates $\mathrm{co}^{-}$ ethnic agglomerations - MNEs from a single country of origin and the co-ethnic communities that can form within them ${ }^{2}$ (e.g., Dana, Etemad, \& Wright, 2008; Guillén, 2002; Head, Ries, \& Swenson, 1995; Henisz \& Delios, 2001; Hernandez, 2014; Kim, 2015; Miller, Thomas, Eden, \& Hitt, 2008; Rangan \& Sengul, 2009; Tan \& Meyer, 2011). We focus on the latter stream and answer the question: How does an initial entry through a co-ethnic community influence MNEs' subsequent subnational location choices and expansion speed within the same host country? We draw on the co-ethnicity perspective from economic sociology (Levitt, 2004; Polanyi, Arensberg, \& Pearson, 1957; Light, 1972, 1983; Portes \& Sensenbrenner, 1993; Rezaei, 2011) and logics from research on the effects of social and geographic proximity (Boschma, 2005; Tong, 2005). Our research responds to calls for finer-grained analyses of subnational MNE locationchoice effects with the goal of improving the specification of IB models (Cantwell \& Brannen, 2011; Cantwell, Dunning, \& Lundan, 2010; Chan, Makino \& Isobe, 2010; Lorenzen \& Mudambi, 2013).

Our study is situated in China because it provides a natural setting with considerable subnational heterogeneity, which may influence investments decisions, and within-country expansion in particular (e.g., Shi, Sun, Pinkham, \& Peng, 2014). Moreover, China continues to be in institutional transition, creating a need for MNEs entering the country to cope with substantial uncertainty (Delios \& Henisz, 2003; Morrison, 2014). Countries in transition exhibit voids in formal market-supporting institutions, resulting in the emergence of informal mechanisms that fill these voids (Kim \& Song, 2016; Peng, 2003; Tong, 2005). In such environments, relationships are a critical part of doing business and therefore foreign MNEs may seek out co-ethnic communities as a strategy to reduce uncertainty (Hernandez, 2014; Kim, 2015; Rezaei, 2011; Tan \& Meyer, 2011). Co-ethnic communities facilitate market transactions through non-market mechanisms - for instance, by aiding business-relationship building and providing access to a qualified labor pool, which can be particularly beneficial during the initial entry stage of a foreign MNE in a new host country (Adler \& Cole, 1993; Ahmadjian, 2016; Florida \& Kenney, 1991; Martin, Mitchell, \& Swaminathan, 1995; Portes \& Sensenbrenner, 1993; Womack, Jones, \& Roos, 1990).
While the benefits of co-ethnic communities for foreign MNEs, especially new entrants, have been discussed, the IB literature has not yet linked entry through co-ethnic communities to the subsequent within-country expansion of foreign MNEs. We regard this as a substantial gap in the literature, because the first subsidiary of an MNE in a host country plays an important role in shaping how the MNE expands in that country (Chang, 1995; Chang \& Rosenzweig, 2001; Gao \& Pan, 2010). We begin to address this gap by demonstrating that an MNE's initial location choice in a host country - within or outside of co-ethnic communities - can have important consequences for its subsequent within-country expansion. An MNE that enters a host country through a location with a strong coethnic community may enjoy sustained benefits such as easier access to financing, social support for expatriates and their families, and access to information and other resources (Hernandez, 2014; Jean, Tan, \& Sinkovics, 2011; Li, Gwon, \& Hernandez, 2015; Miller et al., 2008). This co-ethnic support may affect the MNE's subsequent withincountry location choices and expansion speed, i.e., the rate at which an MNE establishes additional subsidiaries in the host country.

We apply geo-visualization techniques (Andrienko et al., 2010; Pavlovskaya, 2006; Wang, Zhang, Zhang, \& Zhang, 2014) from geographic information science (GIS) to identify Japanese MNE agglomerations in China based on a panel of geocoded subnational investment data. Prior research has generally used fixed administrative units (such as provinces and states) to identify agglomerations of foreign direct investment (FDI). This approach might not have captured the actual proximity perimeters of co-ethnic agglomerations. By defining the boundaries of MNE agglomerations "organically" and over time, rather than based on fixed, predefined administrative units, we are able to "zoom in" and provide a much more nuanced understanding of the within-host-country expansion of foreign MNEs (Morgan, 1998; Waldinger, Aldrich, \& Ward, 1990). We aim to make at least three theoretical and methodological contributions to research and practice.

First, we aim to show that co-ethnic communities represent an important and enduring informal mechanism for bridging market inefficiencies when MNEs face significant institutional uncertainty. By zooming in on co-ethnic agglomerations and their effects on within-country MNE expansion, we extend the core-periphery framework (Benito \& 
Narula, 2007; Mudambi \& Santangelo, 2016; Santangelo, 2009; Wallerstein, 1974) and integrate it with the co-ethnic perspective grounded in economic sociology (Levitt, 2004; Portes \& Sensenbrenner, 1993; Rezaei, 2011). Second, we show how IB research can overcome the need for predefined administrative units and achieve a much more accurate definition of subnational core-periphery regions with the help of geo-visualization methodologies. Third, relaxing the assumptions of administrative boundaries also allows us to look more deeply into the discontinuities, irregularities, and heterogeneity of the spatial evolution of MNEs over time.

\section{HYPOTHESIS DEVELOPMENT}

\section{Core and Periphery Locations}

The core-periphery framework (Benito \& Narula, 2007; Mudambi \& Santangelo, 2016; Santangelo, 2009; Wallerstein, 1974) divides locations into core and periphery, based on the extent of their integration with the world economy (usually operationalized by the volume or density of FDI activity). Periphery locations, which receive little FDI relative to core locations, are characterized by shallow resource pools and limited economic activity. Nevertheless, the periphery may be attractive to MNEs because of the availability of valuable basic resources, such as semi-skilled labor, at a relatively low cost (Mudambi \& Santangelo, 2016; Santangelo, 2009). In addition, governments often provide subsidies and incentives to attract FDI to periphery regions (Cheng, 2014).

Core locations, by contrast, provide diverse and sophisticated resources, attracting large numbers of foreign MNEs (Benito \& Narula, 2007; Goerzen, Asmussen, \& Nielsen, 2013). Repeated interaction between foreign MNEs and local actors may improve information about and access to resources such as labor, infrastructure, and finance (Mariotti et al., 2010; Mudambi, 2002; Spencer, 2008). Interactions among foreign MNEs in core locations may also lead to technology and other knowledge spillovers (Mudambi \& Santangelo, 2016; Santangelo, 2009). However, increasing competition among firms in core locations tends to create substantial upward pressure on the costs of labor, land, and other crucial inputs. In the case of China, significant economic and institutional reforms have taken place in the period we studied (1996-2014). One aspect of development has been government incentives that are explicitly tied to market-based transactions (Zhou, Li, Zhao, \& Cai, 2003) and the geographic push of FDI westward, into the interior of China and away from the coastal cities (Shi et al., 2014). Yet the link between FDI movement and government incentives is tenuous - studies show that even with substantial incentives, the subnational geographic distribution of FDI is not easily malleable (Cantwell \& Mudambi, 2005; Mudambi, 1998). When integrated with the core-periphery framework, this suggests that cores in developing markets tend to have durable, attractive qualities that are difficult to overcome by economic policy targeted at distributing FDI more broadly. Perhaps more importantly, economic sociologists argue that cores tend to be resilient, making it difficult to dislodge them once formed (Waldinger, 1995).

\section{Co-ethnic Cores}

Foreign MNEs rely on relationships driven by the individual MNE's customers, suppliers, and subsidiary networks (Harzing \& Sorge, 2003). Some MNEs seek to replicate relationships from their country of origin in host countries (Florida \& Kenney, 1991; Head et al., 1995; Martin et al., 1995). Within individual host countries, subnational locations with large numbers of MNEs from the same country of origin (co-ethnic agglomerations), coordination between co-ethnic MNEs may lead to the development of co-ethnic communities (Hernandez, 2014; Levitt, 2004; Light, 2010; Miller et al., 2008; Portes \& Sensenbrenner, 1993). Rezaei (2011) described co-ethnic communities as concentrated nodes in relatively restricted spatial areas within global cities, functioning like bazaar-type economies (Dana et al., 2008) based on social norms from the country of origin of the respective co-ethnic community (Shin, Hasse, \& Schotter, 2016). However, only agglomerations that maintain a sufficient number of co-ethnic MNEs can develop into co-ethnic communities, because the local co-ethnic population requires a certain level of co-ethnic activity to establish co-ethnic schools, banks, law firms, and other support services (Chang \& Park, 2005; Rezaei, 2011). While observing and identifying such communities is quite difficult, they are strongly coupled with the density of coethnic agglomerations (Waldinger, 1995). We thus extend the core-periphery framework with the concept of co-ethnic cores - the dense MNE agglomerations that are explicitly tied to co-ethnic communities and their related resources. 
Our distinction between core and periphery along the co-ethnic dimension (Hernandez, 2014; Li et al., 2015; Kim, 2015; Miller et al., 2008; Rezaei, 2011) goes beyond the traditional operationalization of FDI core versus periphery based on administrative units. The traditional approach, which identifies cores based on state, province, or city boundaries with large inward FDI stocks or flows, treats all points within each administrative area as equal. Investments inside a "core" administrative unit are contrasted with investments outside of it ("periphery"). We relax this assumption, by parsing the traditional agglomeration data into much finergrained data at the street level, thus distinguishing between co-ethnic core and periphery within the administrative units that would previously have been classified as monolithic cores. This approach accords with the views of economic sociologists (Dana et al., 2008; Rezaei, 2011) who argue that communities occupy small geographic spaces, and that the true enclave boundaries are more meaningful than official administrative boundaries (Levitt, 2004; Portes \& Sensenbrenner, 1993). The social effects of these communities are thought to be tightly coupled with short geographic distances on the scale of a large city block which facilities identification-based relationships (Lewicki \& Bunker, 1996) underlying social-relations-driven business networks (Rezaei, 2011). Thus it is critical for a co-ethnic MNE to be located within the boundaries of the co-ethnic core, and not just in the proximate area defined by a general administrative region.

Co-ethnic cores offer several advantages to MNEs from the same country of origin. Their shared cultural background, common social norms, and social ties facilitate market interaction and information sharing (Agrawal, Kapur, \& McHale, 2008; Chang \& Park, 2005; Kim, 2015; Li et al., 2015; Miller et al., 2008; Tan \& Meyer, 2011). Moreover, local actors adapt to the concentration of samecountry MNEs by acquiring language and cultural knowledge, which reduces the liability of foreignness faced by MNEs from that particular country of origin (Manning, Sydow, \& Windeler, 2012; Miller et al., 2008; Tan \& Meyer, 2011; Zaheer, 1995). These effects are particularly important for transition economies, where co-ethnic cores help reduce institutional uncertainty, provide information, and facilitate access to support structures such as legal services and financing (Ahmadjian, 2016; Fiske, 2004; Florida \& Kenney, 1991; Tan \& Meyer, 2011, Miller et al., 2008).
While this study examines the role of co-ethnic cores on Japanese FDI in an emerging market China - co-ethnic communities are a more general phenomenon which also plays an important role in developed markets, such as the United States, and which is therefore not restricted to collectivist home countries like Japan (Hernandez, 2014; Miller et al., 2008; Zhu et al., 2012). For instance, co-ethnic colocation and community effects with respect to FDI have been reported for Korean firms (Chang \& Park, 2005; Guillén, 2002; Li et al., 2015), East Asian and Southeast Asian banks (Zhu et al., 2012), North American, European and Asian firms investing in Vietnam (Tan \& Meyer, 2011), and European and Japanese firms investing in the United States (Bobonis \& Shatz, 2007). Moreover, Hernandez (2014) linked co-ethnic immigrant populations to FDI location choice and subsidiary survival, using a sample of MNEs from 27 different home countries investing in the United States. Manning et al. (2012) also showed that German MNEs cooperate with each other and with the German Chamber of Commerce to form "national enclaves" (p. 1215) in a host country, where local labor markets, infrastructure, and institutions are then adapted to cater to the needs of German firms. Co-ethnic ties have further been shown to increase knowledge flows among inventors belonging to the Indian diaspora (Agrawal et al., 2008), and to improve the likelihood of survival of Gujarati-owned hotels in the United States (Kalnins \& Chung, 2006).

A rich literature also exists that documents coethnic communities at the level of individual immigrants and expatriates, which are often concentrated in ethnic enclaves within larger cities (Portes \& Sensenbrenner, 1993; Waldinger et al., 1990). Co-ethnic agglomeration of foreigners in China can be traced back, at least, to the foreign communities that developed in the semi-colonial treaty ports of the nineteenth century (Bickers, 1998; Ma, 2008; Ristaino, 2003). In the context of modern China, scholars have studied co-ethnic communities in several cities, including African traders in Guangzhou (Zhang, 2008), Koreans in Yanji (Kim, 2003), and broader groups of foreign expatriates in Shanghai and Beijing (e.g., Wang \& Lau, 2008; Wu \& Webber, 2004).

\section{The Effect of Co-ethnic Cores on Subsequent Subsidiary Location}

Given the advantages offered by co-ethnic cores, these cores should be highly attractive for MNEs 
entering a host country for the first time. Yet what is not clear in the literature is whether the subnational location of an MNE's first entry - i.e., within a coethnic core or not - affects the MNE's subsequent investments in the host country. Because many MNEs treat their first subsidiary in a host country as a platform for expansion (Chang, 1995; Gao \& Pan, 2010; Chang \& Rosenzweig, 2001; Kogut \& Chang, 1996), the subnational entry location of an MNE may have important implications for its subsequent within-country expansion, including subnational location choices and the speed of expansion. While expansion in the host country can take many forms, we specifically refer to expansion in the sense of MNEs establishing additional, new subsidiaries in other subnational locations. Notably, we do not consider the expansion of existing facilities or repeated investments in the same city. While such repeat investments in a single location are an important type of within-country expansion, they are conceptually distinct from MNE expansion to other subnational locations. Specifically, repeat investments allow MNEs to draw on their own location-specific experience (Mudambi, 1998), which likely reduces the importance of co-ethnic effects. Given our theoretical framing, we thus focus on expansion to new subnational locations and exclude repeat investments.

We expect that the initial entry choice will lead to a preference for similar locations in the case of expansion. MNEs that enter a host country through the periphery must, by necessity, forge close ties with local actors in order to access local resources (Waldinger, 1995). These firms might be able to more easily expand into other periphery locations because they have developed stronger capabilities for building local ties, compared to MNEs that started in co-ethnic cores (Luo, 2002).

On the other hand, MNEs that initially entered the host country through a co-ethnic core benefit from the information and resource advantages associated with these locations. When such an MNE seeks to expand its presence in the host country, it may therefore leverage co-ethnic advantages for establishing additional subsidiaries (Luo, 2002; Tan \& Tan, 2005). In addition, prior research suggests that market information in co-ethnic cores tends to flow easily among co-located MNEs (Hernandez, 2014; Kim, 2015; Tan \& Meyer, 2011), making it relatively easier to expand from one coethnic core to another, instead of venturing into the periphery (Polanyi et al., 1957; Portes \& Sensenbrenner, 1993; Waldinger, 1995). For example, a
Japanese MNE in Dalian might obtain valuable information from other Japanese firms in Dalian about opportunities in another Japanese co-ethnic core, such as Suzhou. It is less likely to obtain information about opportunities in periphery locations, because few Japanese firms operate there. As a result, we expect a co-ethnic core-to-core investment path dependency (David, 1985) to develop, such that MNEs entering the host country through a co-ethnic core are likely to also undertake subsequent investments in other core locations.

This tendency for core-to-core expansion patterns may, in some cases, be mitigated by a redundancy of information. Some MNEs might find it sufficient to establish a presence in one core, which allows them to tap into co-ethnic networks in the host country. With the initial core foothold in place, coethnic cores may be less attractive for subsequent investments because information and other coethnic community benefits are similar across cores, and therefore redundant (Shi et al., 2014). Thus there may be an incentive for MNEs that start in cores to move into the periphery after their initial entry. However, we expect that for most MNEs entering through co-ethnic cores, the relative ease of entering other co-ethnic cores will lead to a pattern of core-to-core expansion. Therefore:

Hypothesis 1: Entering the host country through a co-ethnic core increases the likelihood that an MNE will establish subsequent subsidiaries in other co-ethnic cores, rather than in the periphery.

\section{The Effect of Co-ethnic Cores on the Speed of Within-country Expansion}

The initial entry location in a host country may also influence an MNE's within-country expansion speed, i.e., the rate at which an MNE establishes additional subsidiaries in the host country. If the average Japanese MNE expands at a particular rate, some Japanese MNEs will delay and others will accelerate their within-country expansion. Some of the variation in expansion speed may be attributed to the subnational location of an MNE's first subsidiary in either a co-ethnic core or in the periphery.

MNEs that enter via co-ethnic cores can leverage co-ethnic ties from their original entry location in order to expand their presence in the host country. The co-ethnic community may provide quicker and more trustworthy information on market opportunities, potential partners, and other 
resources facilitating expansion (Ahmadjian, 2016; Miller et al., 2008; Portes \& Sensenbrenner, 1993; Waldinger, 1995). The information sharing and trust-based relationships between co-ethnic MNEs (Lewicki \& Bunker, 1996; Tan \& Meyer, 2011) can be a particular advantage in transition economies, where formal market-supporting institutions are imperfectly developed (Luo, 2002; Peng, 2003; Tan \& Meyer, 2011). A presence in a co-ethnic core, characterized by economic and social networks, may also allow an MNE to dispatch more easily the expatriate managers needed to support the firm's expansion in the host country (Tan \& Mahoney, 2006). An MNE that enters the host country through the periphery may still access these co-ethnic benefits later, by establishing its second or third subsidiary in a coethnic core. However, entering directly through a co-ethnic core ensures that co-ethnic support is available from the start, which should accelerate within-country expansion relative to MNEs that only enter cores later.

By contrast, entry into the periphery may delay the expansion of MNEs. Without a substantial coethnic support network, foreign MNEs may experience greater difficulties in overcoming the liability of foreignness (Zaheer, 1995) and in accessing critical resources (Hernandez, 2014; Tan \& Meyer, 2011), which will then affect the speed of within-country expansion. One reason is that building local embeddedness to access local resources tends to be time-consuming, especially for new entrants, who face a high degree of outsidership and often struggle to gain the trust of local actors due to limited host-country knowledge (Johanson \& Vahlne, 2009; Tan \& Meyer, 2011; Portes \& Sensenbrenner, 1993; Zaheer, 1995). This may reduce the capacity of new entrants to undertake within-country expansions early on. In addition, local embeddedness tends to be specific to each subnational location (Chang \& $\mathrm{Xu}, 2008$; Meyer, Mudambi, \& Narula, 2011), whereas co-ethnic networks link co-ethnic communities in different parts of the host country (Rezaei, 2011), which should facilitate expansion beyond the initial location. Therefore we expect that on average, ${ }^{3}$ initial entry through a co-ethnic core will accelerate an MNE's within-country expansion compared to an initial entry through the periphery. Therefore:

Hypothesis 2: Initial entry into a co-ethnic core will accelerate within-country expansion.
Figure 1 (a) Zoom-out: FDI and co-ethnic cores in China (1996). (b) Zoom-out: FDI and co-ethnic cores in China (2014). Note: FDI data (grey) represents average annual new FDI count from all countries

\section{METHODS}

\section{Data}

We tested our hypotheses using data on Japanese FDI in China between 1996 and 2014. We drew on the Toyo Keizai Inc. dataset (2014 edition), which contains extensive and reliable information on the overseas investments of Japanese firms (Arregle, Miller, Hitt, \& Beamish, 2013), along with the China City Statistical Yearbooks (All China Data Center, 2016), which provide city-level information on inward FDI flows from all FDI source countries. This empirical setting is especially suitable for testing our hypotheses because China is a major recipient of FDI and exhibits significant subnational variation in its economic and institutional development. Moreover, China's relatively recent opening to foreign investment (which coincides roughly with the beginning of our sample period) and the subsequent surge in inward FDI make the country a dynamic research setting that allows us to observe the development of cores and peripheries over time. After accounting for missing data, our analytical sample consisted of 2,536 Japanese MNEs. Our analysis focused on mainland China and excluded the special administrative regions of Hong Kong and Macau.

\section{Defining Core and Periphery with Geo-visualization}

We began by mapping the subnational distribution of FDI inflows in China based on administrative boundaries, in order to show how traditional approaches would define FDI core and periphery locations. Drawing on the China City Statistical Yearbook data, we mapped the entire inward FDI from all foreign source countries. Specifically, we mapped the annual number of newly signed FDI contracts. We used sub-provincial administrative units, such as prefecture-level cities ${ }^{4}$ and sub-provincial municipalities, as geographic units for mapping inward FDI. This is illustrated by the grey-shaded areas in Figures 1a, b and 2, with darker shading indicating more FDI inflows. The maps show that FDI is highly concentrated in a small number of regions in the coastal provinces, which constitute the core locations according to this methodology. 

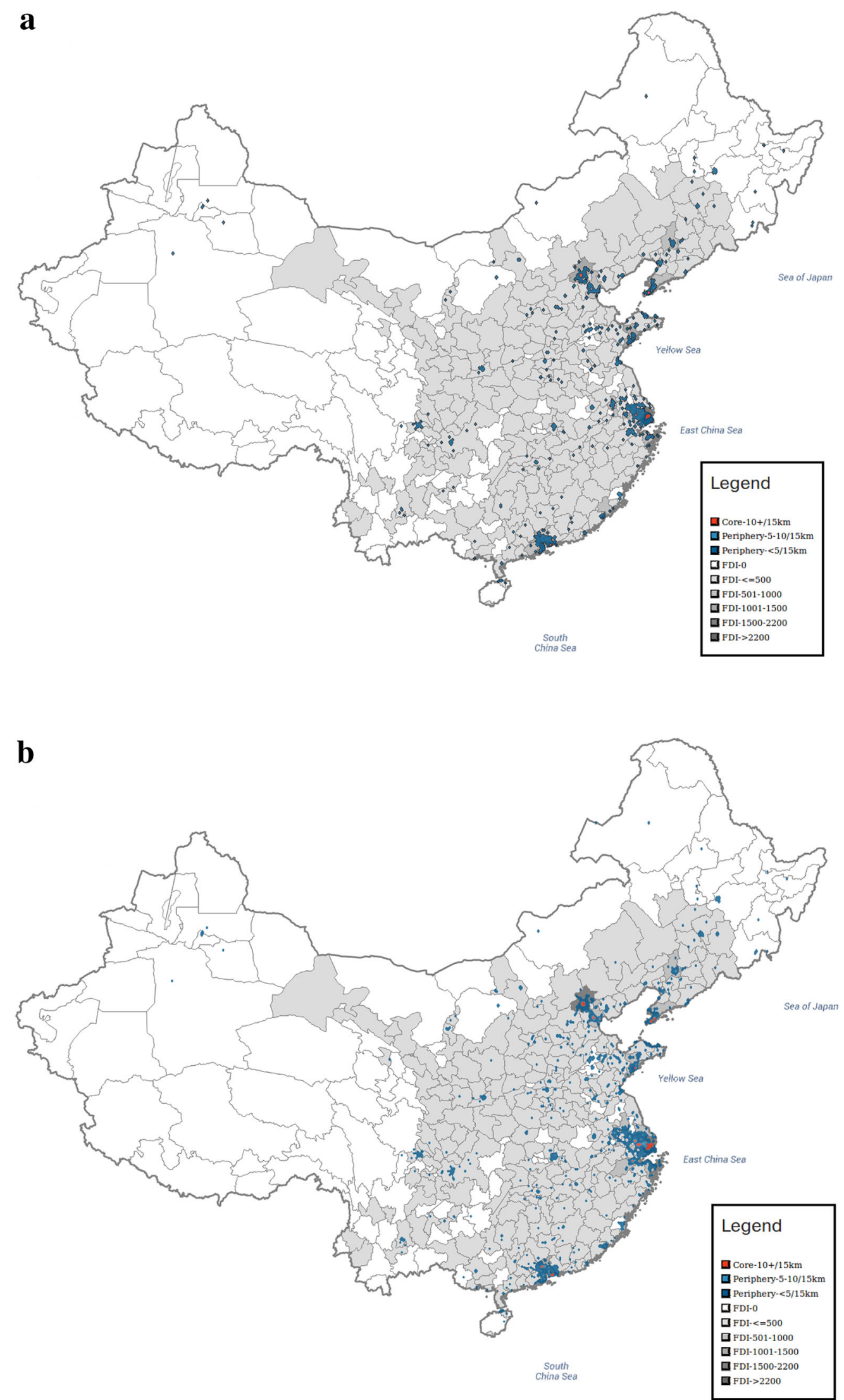


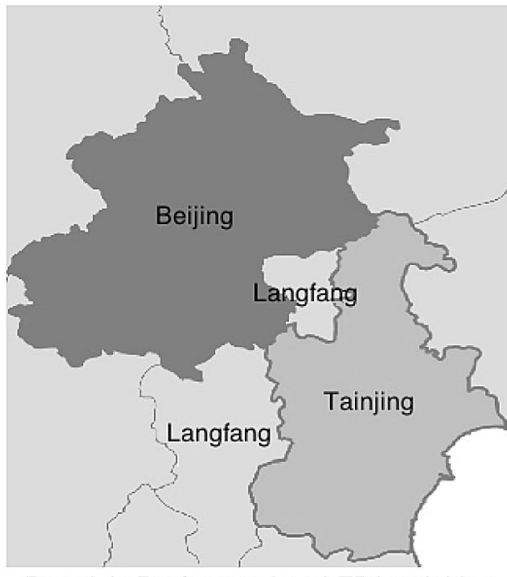

Panel A: Prefecture-level FDI activities

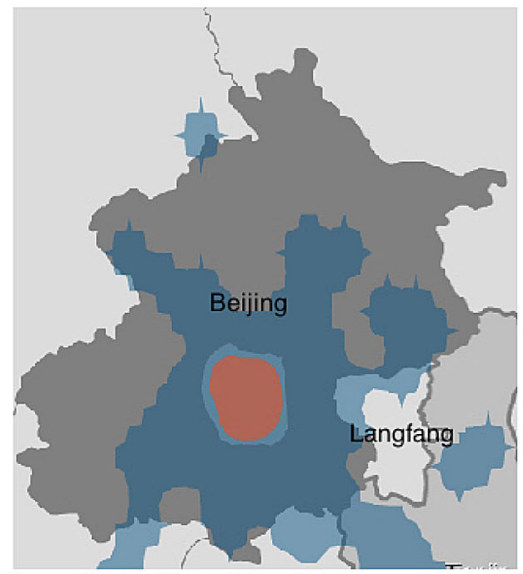

Panel B: Beijing FDI activities and hotspot

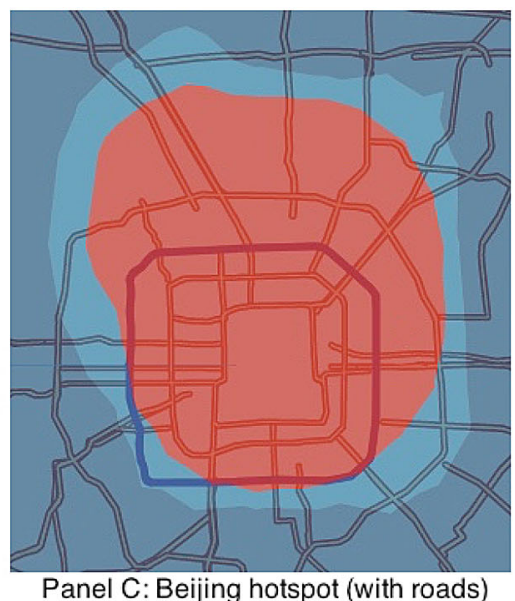

Panel C: Beijing hotspot (with roads)

Figure 2 Zoom-in: FDI and co-ethnic cores in the Beijing region (2014). Note FDI data (grey) represents average annual new FDI count from all countries

The main limitation of this approach is the use of predefined geographic regions for evaluating the concentration of FDI (Alcácer \& Zhao, 2016). Even though we used sub-provincial administrative regions, which are already significantly more finegrained than the provincial boundaries used in most IB studies of China (Bu \& Wagner, 2016; Chan et al., 2010; Li \& Park, 2006; Ma, Tong, \& Fitza, 2013; Schotter \& Beamish, 2011; Shi et al., 2014), the fixed boundaries may nevertheless obscure the underlying core-periphery structure (Alcácer \& Zhao, 2016). For instance, the true size of a core may be exaggerated because non-core locations within the same geographic unit are erroneously included. Additionally, we may fail to detect cores that are located in large geographic units or that straddle administrative boundaries (Alcácer \& Zhao, 2016). To overcome the limitations of predefined geographic units, we defined the boundaries of cores "organically," based on FDI density (Alcácer \& Zhao, 2016). Specifically, we identified subnational core and periphery locations by examining the cumulative stock of Japanese FDI in each location, which we regard as a measure of the co-ethnic support networks available to Japanese firms entering those locations. Leveraging geo-visualization methodology allowed us to integrate data-driven definitions with social theory (Dana et al., 2008; Rezaei, 2011) through deterministic interpolation, and to create a social-based system where all points, even in remote areas, have relationships. This allowed us to determine coethnic cores and peripheries, thus capturing subnational differences more accurately (Alcácer \&
Zhao, 2016; Mudambi \& Santangelo, 2016). It also allowed us to track how the boundaries of cores and peripheries shift over time in response to sustained FDI inflows.

In order to map the cumulative stock of Japanese MNE investments in China, we produced heat maps using kernel density estimation (KDE) (Silverman, 1986), weighted by the average number of foreign investments prior to the focal year. On heat maps, investments are represented as surfaces with high and low values and statistically defined boundaries. High values are at the locations where investment activities are dense; low values are at the locations where activities are sparse. To generate heat maps, we geocoded our FDI data at the street level for all available Japanese MNEs in China from 1991 to 2014, rather than the more restricted analytical sample (1996-2014) used for hypothesis testing. In the rare event that street addresses were unavailable, we incorporated the next-best approximation, such as the district or zip code. Overall, we geocoded 10,633 subsidiaries.

The visualization itself was designed with Google Maps Application Programming Interface, D3.js (a visualization language for web applications), JavaScript, and jQuery. To render the heat map on Google Maps and zoom in on FDI "hotspots," we converted the heat map to an ASCII grid file and rendered the grid with Bourke's contouring algorithm "CONREC" and D3.js (Bourke, 1987). This conversion allowed us to represent the heat map layers in scalable vector graphics (SVG) format, a special type of imagery that can be stretched and reduced through zooming in and out on Google 
Maps. The advantage of SVG imagery for this research is the ability to select Japanese subsidiaries associated with co-ethnic cores throughout China. Although heat maps are traditionally generated for certain zoom levels because geographic processes occur at particular scales, we used a single heat map for all geographic scales. Our rationale was the following: FDI processes are commonly studied at the global scale; therefore, the strongest clusters (cores) have to be identified at the country level, not at the level of smaller geographic locations. Thus when we zoom into the city level, hotspots are still defined relative to all other Japanese MNE investments, and not relative to spatial patterns at the city level.

We explored several methods for determining the cut-off points for subnational cores and the periphery. We found that the agglomeration effects of the Japanese community are strongly distance-bound, experiencing significant diminishing returns after about $15 \mathrm{~km}$ from the origin of agglomeration (Békés \& Harasztosi, 2013). We explored the ranges between the upper and lower boundaries around $15 \mathrm{~km}$, with two criteria from our theory in mind. First, co-ethnic MNEs must be reasonably proximate to form a community (Tan \& Meyer, 2011) and second, there must be a reasonable baseline of co-ethnic MNEs available to reach a critical mass for developing a community effect (Portes \& Sensenbrenner, 1993; Waldinger, 1995). We used a series of clustering exercises to explore co-ethnic MNE number thresholds, and found natural breaks in communities between 10 and 35. We then tested our ranges with geo-visualization sensitivity analyses using confidence-interval mapping (Guo, Gahegan, MacEachren, \& Zhou, 2005). We found that not all co-ethnic investments near agglomerations could be included in the co-ethnic cores. The cores exhibited a center with 4 or 5 confidence intervals. We incorporated only the first confidence interval in our analyses. One justification for this restricted definition was to maintain the geographic scope that we expected for community-based effects from the co-ethnicity literature (Bitters, 2009). In addition, when cores were close or proximate (e.g., Shanghai and Suzhou), several overlapping coethnic investments were at the edge of confidence intervals 4 and 5, leading to very large hotspots. The geo-visual analysis suggested that the most consistent modeling of co-ethnic cores that resemble communities would be a $15-\mathrm{km}$ radius and a minimum of 10 co-ethnic MNEs within each core.
Our geo-visualization not only showed clusters on the maps, but also allowed us to interact with the data and change the visualization on the maps. This allowed us to examine individual subsidiaries in space, examine changes over time, select and classify subsidiaries, and extract data from the map for further statistical analysis. ${ }^{5}$

\section{Dependent Variables}

The dependent variable for Hypothesis 1, subsidiary 2 core, indicates whether an MNE's second subsidiary was located in a core or periphery location. The variable takes the value 1 if the second subsidiary was located in a core location and takes the value 0 otherwise. We tested Hypothesis 2 with a repeated-hazards event history analysis (EHA) (Blomkvist, Kappen, \& Zander, 2010; Box-Steffensmeier \& Zorn, 2001; Ezell, Land, \& Cohen, 2003; Kappen, 2011), with the event of interest being the time of establishment of a focal MNE's second, third and fourth subsidiaries in China.

\section{Independent Variable}

The independent variable for both hypotheses is subsidiary 1 core, which indicates whether an MNE's first entry into China occurred in a co-ethnic core or in the periphery. Subsidiary 1 core takes the value 1 if the focal MNE entered through a core location and the value 0 otherwise.

\section{Control Variables}

We used a number of control variables to account for a range of factors potentially affecting the within-country expansion patterns of MNEs. In order to account for the institutional and economic development of the host country over time, we controlled for the years in which an MNE established its first and second subsidiaries in China, using the variables subsidiary 1 start year and subsidiary 2 start year. Both time variables were scaled such that the start of the sample period, i.e., the year 1996, corresponded to a value of 0 . We also included interaction terms of these time variables with the main independent variable, in order to account for changes over time in the effect of the independent variable. In the model for Hypothesis 1 , we interacted subsidiary 1 core with subsidiary 2 start year, because the strength of the locational path dependency might depend on when the second subsidiary was established. In the model for Hypothesis 2, we interacted subsidiary 1 core with subsidiary 1 start year, because the accelerating 
effect of a core entry might be contingent on the time period in which the initial entry occurred.

We also included a dichotomous control variable for MNEs that established their first Chinese subsidiary within the administrative boundaries of Shanghai (subsidiary 1 Shanghai). Exploratory analyses indicated that Shanghai attracted far more FDI than any other city in China (nearly $32 \%$ of all subsidiaries in our sample). Moreover, FDI characteristics in Shanghai were found to differ from other cities in China in several ways; for example, Shanghai-based subsidiaries tended to be smaller and were less likely to be joint ventures. We thus distinguished between MNEs entering China through Shanghai and those entering through other locations, in order to ensure that the special characteristics of Shanghai were not driving our results.

As the industry of a firm can be expected to affect its location choices and within-country expansion, we included industry control variables at the parent-firm level (Hypotheses 1 and 2) and the subsidiary level (Hypothesis 1). Manufacturing serves as the reference category for both variables, as it is the largest category in the sample (63\% of MNEs; $59 \%$ of subsidiaries). The other categories are retail, wholesale, and services.

Subnational investment location choices likely also depend on the investment purpose of a given subsidiary. For instance, subsidiaries intended to produce goods for local consumption can be expected to be located near lucrative domestic markets, whereas subnational locations with low labor costs may be more attractive to labor-seeking and export-oriented subsidiaries. To take into account such differences in subsidiary objectives, we included a set of dichotomous variables that capture the investment purpose for each subsidiary. The dichotomous purpose variables are: resource seeking; labor seeking; local government incentives; construction of international production network; construction of international distribution network; local market; export to third countries; reverse imports to Japan; following customers, suppliers, and related firms; currency \& financial hedging; knowledge seeking; R\&D; new business; and regional headquarters. The different investment purposes are not mutually exclusive in our dataset, because one subsidiary may serve multiple purposes simultaneously. Hence the reference category for each purpose variable is simply the absence of that particular investment purpose.

Subnational variation in the quality of marketsupporting institutions can impact MNE strategies (Meyer \& Nguyen, 2005; Shi et al., 2014; Zhang,
2013). We controlled for the quality of marketsupporting institutions in the province in which an MNE's first subsidiary was located, in order to distinguish between the effect of the formal institutional environment and the effect of co-ethnic communities. To derive our variable marketization province 1 , we used the marketization index published by China's National Economic Research Institute (Wang, Fan, \& Zhu, 2007). Although this data was only available for the period from 1997 to 2005, the relative ranking of provinces remained remarkably stable over time, such that the most marketized provinces in 1997 were also among the most marketized in 2005. Based on this observation, we used the mean marketization score from the available years for our entire sample period (1996-2013). To test the robustness of this approach, we re-ran our model using only the 1997-2005 period, for which the marketization index was available. Our estimated results were consistent with the full model using the average value of the marketization index.

We further controlled for differences in firm resources by introducing the variable MNE size. This was operationalized as the number of worldwide foreign subsidiaries controlled by the MNE (outside of China) in a given year. Moreover, we accounted for potential experience effects by including the variable international experience, which measures the focal MNE's international experience (in subsidiary-years) outside of China. We standardized both variables.

\section{Econometric Approach}

To test Hypothesis 1, we used logistic regression models to predict the location (core vs. periphery) of MNEs' second subsidiaries. For analyzing the speed of MNE expansion beyond their first subsidiary in the host country (Hypothesis 2), we used repeated-hazards event history analysis (EHA). EHA methodologies (also known as survival analysis) are particularly suitable for studying the occurrence and timing of events when data are right-censored (Allison, 2014; Park \& Ungson, 1997). Our data are right-censored because by the end of the sample period many firms in the sample had not yet expanded beyond one or two subsidiaries in China, and it was unknown whether and when they would expand further. Whereas early EHA methodologies were developed to study duration data related to a single, non-repeatable event (such as death), EHA models have since evolved to accommodate multiple or repeated events (Blomkvist, Kappen, \& 
Zander, 2010; Box-Steffensmeier \& Zorn, 2001; Ezell et al., 2003; Kappen, 2011). Commonly used repeated-hazards models include the Andersen-Gill model (Andersen \& Gill, 1982), the Prentice-Williams-Peterson model (Prentice, Williams, \& Peterson, 1981), and the Wei-Lin-Weissfeld (WLW) model (Wei, Lin, \& Weissfeld, 1989). Although there are advantages and drawbacks associated with each type of model, we adopted the WLW model for two reasons. First, because it is a stratified model, the WLW model does not assume the dependence of subsequent hazards and allows for hazard functions to differ across events for a focal MNE (Ezell et al., 2003; Wei et al., 1989). Thus the model accounts for the possibility that an MNE's hazard of establishing its second subsidiary in a host country might differ from the hazard of the same MNE establishing a third subsidiary, and accounts for the possibility that these hazards might evolve differently over time.

Second, the Prentice-Williams-Peterson model and Andersen-Gill model are rigidly linear in the sense that an MNE is only considered "at risk" for establishing subsidiary $k$ once subsidiary $k-1$ has been established (Ezell et al., 2003; Wei et al., 1989). By contrast, the WLW model allows for the MNE to be simultaneously at risk for multiple subsidiaries (Box-Steffensmeier, \& Zorn, 2001; Ezell et al., 2003). While Prentice-Williams-Peterson model is more appropriate for settings in which events are truly sequential (e.g., multiple CEO successions within the same firm), the WLW model arguably reflects more accurately the reality of MNEs, which may simultaneously pursue several expansion options simultaneously. In testing Hypothesis 2, we considered the second, third, and fourth subsidiaries of MNEs in order to assess within-country expansion. Expansion beyond the fourth subsidiary was excluded from the analysis because of the relatively small number of MNEs in the sample (less than 10\%) that had achieved a footprint of more than four subsidiaries. The WLW model was implemented in Stata using the stcox command with stratification by subsidiary number (i.e., second, third and fourth subsidiaries), and clustering by MNE (Cleves, 2009).

\section{RESULTS}

\section{Geo-visualization Results}

Geo-visualization enabled us to identify Japanese FDI co-ethnic cores and their periphery. At the beginning of our sample period in 1996, we identified four Japanese co-ethnic cores, located in Beijing, Shanghai, Shenzhen, and the northeastern port city of Dalian (see Figure 1a). As more Japanese investment entered the country, additional locations attained co-ethnic core status. Most of these new co-ethnic cores emerged in the vicinity of existing cores, such as Suzhou (2001) and Wuxi (2006) near Shanghai. Other new cores appeared in major cities in coastal provinces, such as Tianjin (2003), Hangzhou (2004), Qingdao (2004), and Guangzhou (2006). In some cases, two distinct Japanese co-ethnic cores emerged within the same city or administrative unit. For instance, Tianjin developed two cores: one in downtown Tianjin and the other in the Tianjin Economic-Technological Development Area located some $40 \mathrm{~km}$ away from downtown. ${ }^{6}$ By 2014, we identified 16 distinct Japanese co-ethnic cores in China located in 11 cities (see Figure 1b and Table 1). Notably, all of these cores are located in coastal provinces. Thus despite government incentives intended to attract foreign MNEs to the interior (Cheng, 2014; Goodman, 2004), and despite rising labor costs and intensifying competition in the coastal centers (Davies, 2013; Economist Intelligence Unit, 2012), investments by Japanese MNEs continue to be highly concentrated in the coastal provinces, and more specifically in a small number of co-ethnic core locations within those coastal provinces.

Two conclusions can be drawn when comparing the geo-visualization of Japanese FDI to the distribution of general inward FDI (from all countries) among subnational administrative units. First, Japanese co-ethnic cores are located within cities (and provinces) that are among the top destinations for FDI from all countries (Figures 1a, b). Second, the geo-visualization confirmed that Japanese FDI and the associated co-ethnic communities are not captured well by administrative boundaries. Not only do we find substantial FDI-based heterogeneity within provinces, but even the finergrained sub-provincial administrative divisions obscure the true core-periphery landscape. We illustrate this effect by zooming in on the Beijing region (Figure 2). The grey-shaded areas represent administrative units, notably the municipalities of Beijing and Tianjin and the surrounding prefecturelevel cities. Darker shading represents higher levels of inward FDI (from all source countries; averaged for the years 2005-2013). The areas in red show the location of the Japanese co-ethnic cores identified by the geo-visualization algorithm (as of 2014). 
Table 1 Location of Japanese co-ethnic cores

\begin{tabular}{lll}
\hline City & Province & Year in which core status was attained \\
\hline Beijing & Beijing* & $1996^{\dagger}$ \\
Dalian (2 cores) & Liaoning & $1996^{\dagger}$ (second core: 2003 ) \\
Shanghai & Shanghai* & $1996^{\dagger}$ \\
Shenzhen (2 cores) & Guangdong & $1996^{\dagger}$ (second core: $\left.1996^{\dagger}\right)$ \\
Suzhou (2 cores) & Jiangsu & 2001 (second core: 2012$)$ \\
Tianjin (2 cores) & Tianjin* & 2003 (second core: 2004) \\
Hangzhou & Zhejiang & 2004 \\
Qingdao & Shandong & 2004 \\
Guangzhou (2 cores) & Guangdong & 2006 (second core: 2006) \\
Wuxi & Jiangsu & 2006 \\
Changzhou & Jiangsu & 2009
\end{tabular}

Notes: * Beijing, Shanghai, and Tianjin are municipalities with province-level status.

$\dagger$ Beginning of sample period.

While the entire administrative region of Beijing is dark grey, indicating high levels of FDI inflows (Figure 2, panel a), the Japanese MNE investment is much more tightly bound (Figure 2, panel b). Zooming in further, we see that the co-ethnic core is concentrated within the city center (Figure 2, panel c). Specifically, the co-ethnic core of Beijing covers most of the area within the 4th Ring Road, which surrounds the inner city (marked by the dark line in Figure 2, panel c), but also extends further to the north and east, where Beijing Capital International Airport is located. Notably, not all locations within the municipal limits of Beijing are part of the co-ethnic core, and less than $60 \%$ of the Japanese subsidiaries in Beijing are located in the Beijing co-ethnic core. This illustrates how geovisualization allows us to "zoom in" further than most previous studies, and to distinguish between core and non-core locations even within the same city. We show below that this increased precision can make a meaningful difference in empirical models.

\section{Econometric Results}

Table 2 reports the summary statistics and correlations. $^{7}$ Variance inflation factors (VIFs) for all variables were below 3.5 for all of our models. Although the correlation between international experience and MNE size was relatively high, the VIFs associated with these variables were below 2, suggesting that multicollinearity was not an issue (Hair, Black, Babin, \& Anderson, 2010). Table 3 presents the results from the logistic regression used to test Hypothesis 1, which predicted that entry through a co-ethnic core increases the likelihood that an MNE will establish subsequent subsidiaries in co-ethnic cores, rather than in the periphery.
Model 1 serves as the base model for this hypothesis, while Model 2 introduces the independent variable subsidiary 1 core. In Model 2, the odds ratio associated with subsidiary 1 core is significantly greater than one $(p<0.05)$, indicating that the odds of a second subsidiary being in a co-ethnic core are higher for MNEs whose first subsidiary was in a co-ethnic core than for MNEs whose first subsidiary was in the periphery. Thus Hypothesis 1 is supported. Moreover, there appears to be an interaction effect between subsidiary 1 core and subsidiary 2 start year (marginally significant, $p=0.05$ ). Whereas the statistical significance of the interaction term does not constitute a valid test of moderation when evaluating non-linear models in terms of marginal (probability) effects (Ai \& Norton, 2003; Wiersema \& Bowen, 2009), we are interpreting our model in terms of multiplicative effects (odds ratios). For multiplicative effects, we can interpret the interaction terms directly (Buis, 2010). Because of the interaction effect, the main effect should be interpreted as the impact of subsidiary 1 core when the interacting variable is equal to 0 (Buis, 2010; Singer \& Willett, 2003). In this case, a value of 0 for the interacting variable (subsidiary 2 start year) corresponds to the year 1996. Thus for MNEs that established their second subsidiary in 1996 and whose first subsidiary was in a core, the odds of the second subsidiary also being located in a core are 3.5 times the odds for a comparable MNE that established its first subsidiary in the periphery (odds ratio 3.51, p $<0.05$ ). For second subsidiaries established after 1996, the effect diminishes every year by approximately $7 \%$ (odds ratio 0.93, $\mathrm{p}=0.05$ ).

In order to aid interpretation of these findings, we performed an additional slope analysis (not 


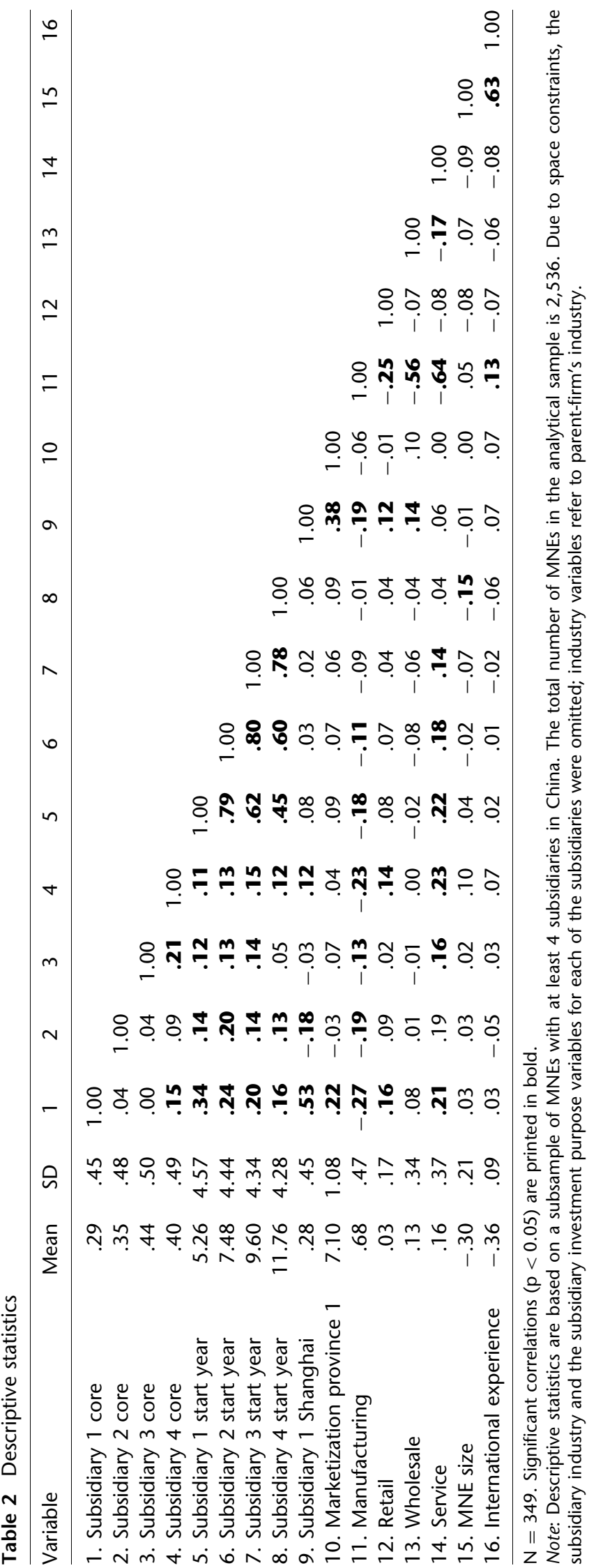


Table 3 Logistic regression results for location of second subsidiaries: Hypothesis 1

\begin{tabular}{|c|c|c|c|c|}
\hline \multirow[t]{2}{*}{ Model } & \multicolumn{2}{|c|}{ Model 1} & \multicolumn{2}{|c|}{ Model 2} \\
\hline & Odds ratio & SE & Odds ratio & SE \\
\hline Subsidiary 1 core & - & - & $3.51^{*}$ & 1.71 \\
\hline Subsidiary 1 start year & 0.97 & 0.03 & 0.96 & 0.02 \\
\hline Subsidiary 2 start year & $1.06^{*}$ & 0.03 & $1.08^{* *}$ & 0.03 \\
\hline Subsidiary 1 core $\times$ subsidiary 2 start year & - & - & $0.93^{\dagger}$ & 0.04 \\
\hline Subsidiary 1 Shanghai & $0.22^{\star \star \star}$ & 0.05 & $0.18^{\star * \star}$ & 0.05 \\
\hline Marketization province 1 & 1.10 & 0.09 & 1.09 & 0.09 \\
\hline \multicolumn{5}{|l|}{ Parent industry (base: manufacturing) } \\
\hline Retail & 1.22 & 0.89 & 1.25 & 0.91 \\
\hline Wholesale & 1.10 & 0.31 & 1.07 & 0.31 \\
\hline Service & 0.66 & 0.27 & 0.65 & 0.27 \\
\hline \multicolumn{5}{|l|}{ Subsidiary industry (base: manufacturing) } \\
\hline Retail & $6.57^{*}$ & 4.81 & $6.24^{*}$ & 4.52 \\
\hline Wholesale & $10.79 * * *$ & 2.60 & $10.58^{* * *}$ & 2.55 \\
\hline Service & $8.26^{* * *}$ & 3.18 & $7.72^{\star \star *}$ & 2.99 \\
\hline \multicolumn{5}{|l|}{ Controls for subsidiary investment purpose } \\
\hline Resource seeking & 0.44 & 0.31 & 0.46 & 0.32 \\
\hline Labor seeking & 0.63 & 0.21 & 0.60 & 0.20 \\
\hline Government incentives & 1.28 & 0.72 & 1.41 & 0.79 \\
\hline Int'l production network & $0.45^{* *}$ & 0.12 & $0.44^{\star *}$ & 0.11 \\
\hline Int'| distribution network & $1.97^{*}$ & 0.57 & $2.02^{*}$ & 0.59 \\
\hline Local market expansion & 1.17 & 0.26 & 1.18 & 0.27 \\
\hline Export to third country & 0.94 & 0.55 & 0.88 & 0.51 \\
\hline Reverse imports to Japan & 0.82 & 0.35 & 0.88 & 0.37 \\
\hline Following customers, suppliers, related firms & 0.74 & 0.28 & 0.78 & 0.30 \\
\hline Currency \& financial risk management & 1.93 & 2.08 & 2.12 & 2.29 \\
\hline Information \& knowledge seeking & 1.43 & 0.52 & 1.46 & 0.54 \\
\hline$R \& D$ & 0.96 & 0.42 & 0.92 & 0.40 \\
\hline Expansion into new business & 1.08 & 0.53 & 1.04 & 0.50 \\
\hline Regional headquarters & 1.96 & 2.07 & 2.26 & 2.42 \\
\hline MNE size & 1.68 & 1.16 & 1.52 & 1.07 \\
\hline International experience & 1.17 & 1.34 & 1.20 & 1.38 \\
\hline Constant & $0.19^{*}$ & 0.13 & $0.16^{\star *}$ & 0.11 \\
\hline Log likelihood & -466.80 & & -463.23 & \\
\hline $\mathrm{N}$ & $972^{a}$ & & $972^{\mathrm{a}}$ & \\
\hline
\end{tabular}

Notes: The base outcome is the location of subsidiary 2 in the periphery.

${ }^{\dagger} p<0.10,{ }^{*} p<0.05,{ }^{* *} p<0.01,{ }^{* * *} p<0.001$.

a Out of the analytical sample of 2,536 MNEs, 972 MNEs established two or more subsidiaries in China.

reported) based on the predicted probability of establishing second subsidiaries in cores (e.g., Blevins, Moschieri, Pinkham, \& Ragozzino, 2016). When an MNE established a second subsidiary in 1996, the predicted probability of that subsidiary being in a co-ethnic core was 0.45 for MNEs with a first subsidiary in a core, versus 0.26 for MNEs with a first subsidiary in the periphery. This is a difference in probability of about $0.20(\mathrm{p}<0.01)$. For second subsidiaries established in later years, that gap shrinks over time and diminishes by the end of the sample period. While the analysis suggests that this gap is shrinking, the data are right-censored, meaning that the second subsidiary investments are yet to be observed for many MNEs in this later period. For this reason, we interpreted the slopes only, and not the difference in slopes between 1996 and 2012. The average marginal effect of a $s u b$ sidiary 1 core was $0.08(\mathrm{p}<0.05)$, suggesting that the probability of the second subsidiary being in a core was, on average, about eight percentage points higher if the first subsidiary was in a core. ${ }^{8}$

Our second hypothesis proposed that first entry through a core location accelerates subsequent expansion in the host country. We predicted the formation of MNEs' second, third, and fourth subsidiaries using the WLW model (Wei et al., 1989). Table 4 reports the results. Building on 
Table 4 Repeated-hazards event history analysis of within-country expansion (subsidiaries 2-4): Hypothesis 2

\begin{tabular}{|c|c|c|c|c|}
\hline \multirow[t]{2}{*}{ Model } & \multicolumn{2}{|c|}{ Model 1} & \multicolumn{2}{|c|}{ Model 2} \\
\hline & Hazard ratio & Std. error & Hazard ratio & Std. error \\
\hline Subsidiary 1 core & - & - & $1.47^{\star \star}$ & 0.22 \\
\hline Subsidiary 1 start year & 0.99 & 0.01 & 1.00 & 0.01 \\
\hline Sub 1 core $\times$ sub 1 start year & - & - & $0.94^{\star *}$ & 0.02 \\
\hline Subsidiary 1 Shanghai & $0.74^{* *}$ & 0.07 & $0.77^{* *}$ & 0.08 \\
\hline Marketization province 1 & 1.03 & 0.04 & 1.02 & 0.04 \\
\hline \multicolumn{5}{|c|}{ Parent industry (base: manufacturing) } \\
\hline Retail & $1.74^{*}$ & 0.44 & $1.82^{*}$ & 0.46 \\
\hline Wholesale & 1.14 & 0.13 & 1.13 & 0.14 \\
\hline Service & 1.02 & 0.13 & 1.03 & 0.13 \\
\hline MNE size & $1.73^{* * *}$ & 0.13 & $1.73^{* * *}$ & 0.13 \\
\hline International experience & $0.86^{*}$ & 0.06 & $0.86^{*}$ & 0.06 \\
\hline Log pseudo-likelihood & $-9,555.40$ & & $-9,547.13$ & \\
\hline $\mathrm{N}$ & 2,536 & & 2,536 & \\
\hline
\end{tabular}

Note: The model predicts the hazard of expansion (creation of subsidiaries 2-4). Hazard ratios greater than 1 indicate an accelerating effect, while hazard ratios below 1 indicate a delaying effect. The Wei-Lin-Weissfeld model is a repeated-hazards Cox model, stratified by subsidiary sequence number, with subsidiaries clustered by MNE. The Efron method was used to resolve ties.

${ }^{*} p<0.05,{ }^{* *} p<0.01,{ }^{* \star *} p<0.001$.

Model 1, Model 2 introduces the covariate subsidiary 1 core and an interaction term with time. Because the WLW model is a type of stratified Cox model, both the duration variable (which measures time to subsidiary formation) and the stratification variable (which distinguishes subsidiaries 2-4) are implicit and thus do not produce coefficient estimates (Box-Steffensmeier \& Zorn, 2001). As with a simple Cox proportional hazard model, hazard ratios greater than 1 indicate that a covariate has an accelerating effect on the event(s) of interest, as it increases the hazard of the event's occurrence (Allison, 2014; Singer \& Willett, 2003). By contrast, a hazard ratio between 0 and 1 indicates a decelerating effect, as the baseline hazard is multiplied by a factor of less than 1 (Allison, 2014; Singer \& Willett, 2003). Because the model predicts three slightly different types of events (the formation of second, third, and fourth subsidiaries), the hazard ratio represents the average effect of the covariate on these three types of events (Box-Steffensmeier \& Zorn, 2001; Ezell et al., 2003). The hazard ratio associated with subsidiary 1 core is greater than 1 , indicating that initial entry into a core location is associated with significantly faster subsequent expansion in the host country $(\mathrm{p}<0.01)$. As with Hypothesis 1, the main effect is interpreted as the effect in the year 1996, when the interacting variable subsidiary 1 start year takes a value of zero. Thus a first subsidiary established in 1996 in a core increased the hazard of subsequent expansion by approximately 47\% (hazard ratio: $1.47, \mathrm{p}<0.01$ ), compared to a first subsidiary established in the periphery. Hence Hypothesis 2 is supported. However, the hazard ratio of $0.94(\mathrm{p}<0.01)$ associated with the interaction term suggests that the accelerating effect of an initial core entry is not stable over time (Buis, 2010). The accelerating effect seems to be largest for MNEs entering China at the beginning of the sample period in 1996. For MNEs entering China later, the accelerating effect of the initial core entry on subsequent subsidiary formation weakens (by approximately 6\%) for each year after 1996.

With respect to our control variables, a noteworthy finding was that first subsidiaries within the administrative boundaries of Shanghai are associated with significantly different expansion patterns, compared to the rest of China. Specifically, subsequent subsidiaries are much less likely to be located in a core, and the hazard of expansion is significantly lower than for MNEs whose first subsidiary was not in Shanghai. We examined this phenomenon with supplementary analyses, which we discuss in the robustness analyses section below.

\section{Robustness Analyses}

We examined to what extent our analyses using geo-visualization-based cores and peripheries led to different empirical conclusions than equivalent analyses using administrative boundaries to identify cores and peripheries. For this comparison, we again used prefecture-level cities as administrative units and ranked them by city-level FDI inflows. 
We identified several different sets of "city cores," using either Japanese FDI or FDI from all source countries, and experimenting with different cut-off values (e.g., Top 3, Top 5, and Top 10 FDI-attracting cities). We then re-ran our models with these citycores instead of the geo-visualization-based cores. In contrast to the geo-visualization-based models reported above, Hypotheses 1 and 2 were not supported in any of the models with cores defined by administrative units.

We further investigated the incremental effect of the geo-visualization-based cores over cores defined by city boundaries. For this purpose, we re-ran our model for Hypothesis 2 on a subsample including only MNEs that entered China through one of the Top 5 FDI-attracting cities. Any significant effect of our geo-visualization-based cores within this subsample would indicate that even within these cities, which are highly attractive to foreign firms, it makes a measurable difference whether the initial subsidiary was located inside or outside of the coethnic core. We found that this is indeed the case: a first subsidiary in the co-ethnic core, compared to other locations within a Top 5 city, increases the hazard of expansion by over $60 \%$ (hazard ratio $1.64, \mathrm{p}<0.01)$.

Given that the control variable for Shanghai indicated significant differences between Shanghai and other locations, we also tested whether the effect of initial subsidiary location (core or periphery) differed between Shanghai and other locations. However, the interaction between Shanghai and subsidiary 1 core did not significantly improve model fit in the models for either hypothesis $(p>0.10)$. Hence we concluded that the core/ periphery effect does not differ systematically between Shanghai and the rest of the country.

Finally, we expected the knowledge intensity of MNEs to affect their location preferences, because core and periphery locations are thought to differ in their resource endowments (Cantwell \& Mudambi, 2011; Mudambi \& Santangelo, 2016; Santangelo, 2009). Specifically, core locations tend to offer better access to diverse and sophisticated knowledge resources than non-core locations, which might make them more attractive for knowledge-intensive firms (Mudambi, 2008). By contrast, periphery locations may offer cost advantages for less knowledge-intensive activities (Mudambi \& Santangelo, 2016). Although data limitations precluded us from incorporating R\&D intensity in our main model, we analyzed a subsample of publicly listed firms for which R\&D data was available.
Although R\&D intensity appeared to be positively correlated with the first and second subsidiary locations in the core, coefficients were not significant $(p>0.10)$ once all control variables were included.

\section{DISCUSSION}

We find support for the argument that an initial entry in a co-ethnic core is associated with subsequent core investment and accelerated subsidiary formation. This has important implications for theory and practice. Our findings suggest that the initial subnational entry location of an MNE can have long-term consequences for the MNE's subsequent development in a specific host country. On the one hand, co-ethnic cores facilitate expansionlocation identification, particularly other co-ethnic cores, and thus might be effective means for mitigating liabilities of foreignness and outsidership (Johanson \& Vahlne, 2009) and difficulties associated with operating in environments with otherwise weak formal market-supporting institutions (Hernandez, 2014; Miller et al., 2008; Tan \& Meyer, 2011). On the other hand, the tendency of MNEs to remain in co-ethnic cores may also reflect the constraining effect of co-ethnic communities (Kim, 2015; Laursen, Masciarelli, \& Prencipe, 2012). MNEs that enter the host market through co-ethnic cores may fail to develop the requisite local knowledge for expanding beyond co-ethnic cores. ${ }^{9}$ This type of entrenchment could prevent MNEs from exploiting opportunities and recourses located in periphery locations (Manning et al., 2012; Mudambi \& Santangelo, 2016). To look more deeply into this nuance of the models, we also considered the financial performance associated with core-to-core expansion strategies, both in terms of revenue growth and subsidiary survival. We did not find a strong performance connection with core-to-core expansion strategies, relative to other expansion strategies (not reported). This is consistent with conversations in the literature and offers a key takeaway for managers - entry in a coethnic core does not appear to positively influence survival or performance and may lead to entrenchment that makes it difficult to expand beyond cores. However, we believe that further research investigating the performance outcomes of core entry and expansion strategies is warranted.

Our motivation for this study was to push theory development by offering an alternative to how we treat FDI data in IB research in general and at the 
subnational host-country level in particular. For instance, institution-based scholars have highlighted the attractiveness of (subnational) administrative regions with strong market-supporting institutions. However, these studies aggregate FDI data within administrative units, such as provinces or states, for which institutional data is available (e.g., Chan et al., 2010; Li \& Park, 2006; Ma, Tong, \& Fitza, 2013; Schotter \& Beamish, 2011; Shi et al., 2014). Notably, more recent work in the global cities literature pushes the boundaries of these aggregate measures of FDI (Goerzen et al., 2013; Blevins et al., 2016). We have taken the next step by "zooming in" further than even the relatively finegrained prefecture-city level. We show that the precise location within such administrative units matters. For instance, among the subset of MNEs that entered China through one of the Top 5 FDIreceiving cities, we found significant differences in expansion speed between MNEs that entered through the co-ethnic cores of these cities, and MNEs that entered through a Top 5 city but outside of the co-ethnic cores. This supports the notion of co-ethnic cores as spatially limited areas - or enclaves - within major cities (Kim, 2003; Wang \& Lau, 2008; Zhang, 2008), within which social relationships between co-ethnic firms enable bazaar-type exchanges (Dana et al., 2008). We illustrate the spatial limits of these co-ethnic cores, using Beijing as an example (Figure 2) - the coethnic core is mostly contained within the 4th Ring Road in the city center, and large parts of the city are classified as periphery.

Further, our empirical analysis, which controls for province-level formal institutions, suggests that location in a co-ethnic core has effects above and beyond those of formal institutions. It is possible that past studies using administrative boundaries have conflated the effects of institutions and coethnic agglomerations, because in practice agglomerations tend to occur in institutionally more developed subnational regions. Our study represents an improvement in the delineation between the effects of co-ethnic agglomeration from institutional effects.

Finally, we respond to calls for better integration of geospatial analysis in FDI research and the utilization of organic definitions of geographic space (Alcácer \& Zhao, 2016). To this end, we enrich this emerging field of subnational analysis by operationalizing and empirically testing the relationships among organically estimated cores. Using KDE allowed us to leverage deterministic interpolation and smoothing techniques to create well-defined spaces. KDE measures cell densities in a grid of points by using a sample of known points. This contrasts with the method described in Alcácer and Zhao (2016), because KDE does not show clusters based on volume alone. Instead, the method generates predicted values for specified spatial locations using a limited number of sample data points at nearby locations. This provides an avenue for leveraging smaller- $\mathrm{N}$ samples that may otherwise go unnoticed. The KDE method may also be preferable over clustering analysis alone because FDI datasets (a) are often finite, (b) are not uniformly distributed among smaller area units, and (c) have unevenly distributed activities (Krugman, 1991; Overman, Redding, \& Venables, 2001; Venables, 1995, 2006). While sample sizes in metropolitan areas are much larger, clustering does not account for restrictions set by provinces and other subnational locations where volume is low and dispersed. To overcome this issue, we follow the GIS literature and treat these data collectively through interpolation before using them in geographic analyses of relationships between businesses or concentrations of economic activity (Meng, Law, \& Thompson, 2010).

\section{LIMITATIONS AND FUTURE DIRECTIONS}

Our research is subject to some limitations. First, the starting point for our analysis was that the subnational location decisions of Japanese MNEs involved existing co-ethnic cores and peripheries at the time of investment. Thus we did not incorporate a discussion of the emergence of these initial cores. However, geo-visualization showed that coethnic cores tended to emerge in regions that attracted large amounts of FDI overall, rather than just co-ethnic FDI. This provides two potential pathways for future research. First, there is an opportunity to explore the underlying mechanism for initial co-ethnic core formation that is different from other agglomeration drivers and to test whether there are geographic and temporal limits to the establishment of new cores. What remains potentially unobserved are the pressures that drive co-ethnic MNEs to "circle up the wagons" in order to carve out a geographic space to sustain and support other co-ethnic MNEs. The second pathway is to look more closely at the patterns of periphery-based expansion. Whereas the core-periphery literature predicts a dispersion of actors in the periphery as a result of limited resources and 
resource lock-up by early entrants (Mudambi \& Santangelo, 2016), our geo-visualization analysis generated some evidence that co-ethnic MNEs also tend to collocate in the periphery. We suggest that a series of empirical studies may lead to a predictive theory of co-ethnic core formation in periphery locations.

Second, the dichotomous structure of the coreperiphery framework may obscure more nuanced subnational differences. Our analysis assumes that a location becomes a co-ethnic core once a threshold density of co-ethnic FDI activity has been reached. This leaves open the possibility of a hierarchy of cores, where cores with very high densities of coethnic firms have different effects on MNEs than cores that barely exceed density threshold levels. These locations may have hybrid characteristics that differ from both core and periphery locations, which may have implications for MNE location and expansion decisions. Therefore we explored some of these possibilities in a number of supplementary sensitivity analyses (not reported). We used alternative cut-off values for co-ethnic agglomerations, introduced an intermediate category of "secondary core," and distinguished between specific cores (e.g., Shanghai core versus Beijing-Tianjin core versus Shenzhen core, etc.). However, most of these modifications did not result in meaningful improvements to our model in the context of the theory development objectives of this study. Future research could explore the effects of layered coreperiphery boundaries. Similarly, there may be important differences among periphery locations for instance, between those in coastal provinces and those in the remote interior. Future research could refine our idea of co-ethnic cores and peripheries by examining their composition more closely. In particular, a focus on boundaries, hierarchies, and collocating consistency over time may be fruitful.

Third, using an exclusively Japanese sample might have limited our analysis. Although studying investment from a single country of origin allowed us to control for several home-country effects, this might have reduced our ability to extend these effects to FDI more broadly. Specifically, Japanese firms may differ from MNEs from other countries in how they are influenced by home-country embeddedness (Ahmadjian, 2016). For instance, the embeddedness and co-ethnic literatures maintain that Japanese firms tend to have very high ethnic cohesion in geographic clusters (Head et al., 1995; Hernandez, 2014; Waldinger, 1995). Although our literature review showed that the phenomenon of co-ethnic co-location is by no means unique to Japanese firms, the strength of co-ethnic community effects, and their specific manifestation in strategic choices of firms, may differ between firms from different home countries. Thus future research should establish the boundary conditions of our findings by replicating our study in different home- and host-country settings.

Fourth, the focus on China as the research setting (despite the advantages outlined above) also has some drawbacks. Most notably, the location choices of MNEs in certain industries were at times restricted by government regulation (primarily during the very early part of our sample period). We sought to control for this by introducing measures for the timing of initial and subsequent investments. Future studies could address these limitations by using data from multiple home and host countries and by structuring the data around advanced time-sensitive modeling.

Finally, we view the core-periphery framework and the notion of co-ethnic agglomerations as complementary to other existing perspectives on FDI and subnational diversity. For instance, we fully acknowledge the importance of institutional frameworks (Peng, Sun, Pinkham, \& Chen, 2009; Peng, Wang, \& Jiang, 2008) at the national and subnational levels for explaining FDI flows. We control for formal market-supporting institutions at the provincial level using the marketization index (Wang et al., 2007), which is a typical measure of institutional development employed in extant China research (Shi et al., 2014). However, we believe that more work needs to be done in this space, because available measures of institutional development have very limited accounts of informal institutional differences. Whereas some formal institutions (such as provincial regulations and city bylaws) may be reflected by subnational administrative boundaries, informal institutions such as acceptance of foreign MNEs (Schotter \& Beamish, 2011) might more closely map onto the core-periphery landscape, which transcends administrative boundaries. Projects that triangulate field research with archival sources for elaborating our findings related to informal institutions and coethnicity in particular are warranted. Overall, we suggest that there is a need to further integrate the core-periphery framework and the effects of coethnic agglomerations discussed in our study with a broader institutional perspective. 


\section{CONCLUSION}

This study contributes to the understanding of subnational core and periphery locations and their relation to the expansion patterns of foreign MNEs. First, we add to theory by showing how the informal mechanism of co-ethnic agglomerations may facilitate the expansion of co-ethnic MNEs within China. We also add to the emerging subnational application of the core-periphery framework (Mudambi \& Santangelo, 2016; Santangelo, 2009) by uncovering a specific mechanism, available in a subset of cores, that allows co-ethnic MNEs to bridge markets that are inefficient or in transition. In addition, we focus on co-ethnic FDI - i.e., investment from a specific country of origin and the agglomeration of MNEs from that country of origin. Geocoded FDI activities guided our determination of whether Japanese MNEs are able to tap into coethnic community resources, which allowed us to provide a better understanding of subnational heterogeneity. We thus introduce a more nuanced approach to the treatment of foreign investment locations and MNE agglomeration (Meyer et al., 2011; McCann \& Mudambi, 2005). We show that an MNE's initial subnational location matters, by demonstrating that the initial location creates a path dependency for the MNE's subsequent withincountry expansion. Finally, through geo-visualization we bring new methodological techniques from adjacent research domains to IB for identifying previously overlooked heterogeneity in FDI flows. This provides alternative paths for IB research to deepen our understanding of subnational FDI patterns, as well as their antecedents and effects.

Our research has several important implications for MNE executives concerned with foreign market entry and expansion decisions. First, for executives it is critical to understand that entry in a co-ethnic core can create path dependencies with respect to subsequent investments in the host country. Coethnic cores are attractive locations for initial entry because the co-ethnic community can provide resources and information, which tends to accelerate within-country expansion and facilitate expansion to other co-ethnic cores in the same country. However, dependence on co-ethnic support and the tendency to expand to other core locations may prevent MNEs from realizing opportunities in periphery locations (Mudambi \& Santangelo, 2016). Second, our research suggests that executives should pay close attention to the actual geographic proximity of potential investment sites to other co-ethnic MNEs, because the benefits of co-ethnic communities are sensitive to geographic distance. Therefore even within city-level boundaries, the choice of neighborhood matters.

\section{ACKNOWLEDGEMENTS}

Earlier versions of this article were presented at the 2015 iBegin Conference in Philadelphia and at a special issue workshop at the 2016 Academy of International Business Annual Meeting in New Orleans. First of all, we thank the anonymous reviewers for their valuable comments and direction throughout the revise and resubmit process. Further, we would like to recognize the hard work and input of the special issue editors, and in particular Ram Mudambi's editorial guidance and support. We also thank Paul Beamish and John Cantwell for their developmental comments along the way.

\section{NOTES}

${ }^{1}$ There is also a well-established economic geography literature on MNE clusters and connectivity (see Lorenzen \& Mudambi, 2013) that emphasizes the importance of local geography.

${ }^{2}$ When firms (and individuals) from the same home country interact in close geographic proximity, they may form co-ethnic communities characterized by ongoing social relationships, trust based on homecountry social norms, and support infrastructure such as home-country banks, schools, and social services. Because many of the nuances of co-ethnic communities are difficult to observe, we focus on the observable outcome of co-ethnic FDI activity that is tightly coupled with the observed presence of co-ethnic communities in the literature: co-ethnic agglomeration. Below, we further introduce the term co-ethnic cores to refer to locations with particularly dense co-ethnic agglomerations, in which the co-ethnic community should be particularly strong.

${ }^{3}$ It is also conceivable that entry into the periphery accelerates MNE expansion in some cases. The reason is that periphery locations may not be able to meet all the resource requirements of the entering MNE. Thus the MNE may need to establish additional subsidiaries in order to pool resources across subnational locations, which could result in an accelerated expansion rate. We regard this phenomenon as the exception. 
${ }^{4}$ The so-called "prefecture-level cities" are the main sub-provincial administrative unit in China. Notably, prefecture-level cities consist not just of a single urban area, but usually include several counties, lower-tier cities, and rural areas (Lin \& Zhang, 2015).

${ }^{5}$ Our geo-visualization is much more interactive than comparable maps produced with $\mathrm{R}$ packages such as Leaflet (Graul, 2016) or RgoogleMaps (Loecher \& Ropkins, 2015). Interactions on maps produced with $\mathrm{R}$ packages generally only allow users to zoom in and out and probe specific locations, without integrating other research methods. Our approach, in addition to the numerous analytical tools embedded in the geovisualization, allowed us to select groups of subsidiaries on the map (e.g., subsidiaries in cores) and extract their data for further statistical processing in Stata.

${ }^{6}$ http://www.china.org.cn/english/SPORT-c/75871. htm.

${ }^{7}$ Note that subsidiary 3 start year and subsidiary 4 start year were included for completeness in the correlation matrix. Even though these variables were not explicitly entered into our models, they underpin the repeated-hazards model used to test Hypothesis 2.

${ }^{8}$ Although the focus of this article was specifically on MNE expansion to new subnational locations within

\section{REFERENCES}

Adler, P. S., \& Cole, R. E. 1993. Designed for learning: A tale of two auto plants. Sloan Management Review, Spring: 85-94.

Agrawal, A., Kapur, D., \& McHale, J. 2008. How do spatial and social proximity influence knowledge flows? Evidence from patent data. Journal of Urban Economics, 64(2): 258-269.

Ahmadjian, C. L. 2016. Comparative institutional analysis and institutional complexity. Journal of Management Studies, 53(1): $12-27$.

Ai, C., \& Norton, E. C. 2003. Interaction terms in logit and probit models. Economics Letters, 80(1): 123-129.

Alcácer, J., \& Zhao, M. 2016. Zooming in: A practical manual for identifying geographic clusters. Strategic Management Journal, 37(1): 10-21.

All China Data Center. 2016. China city statistics. http:// chinadataonline.org. Accessed July 18, 2016.

Allison, P. D. 2014. Event history and survival analysis. Thousand Oaks, CA: Sage Publications.

Andersen, P. K., \& Gill, R. D. 1982. Cox's regression model for counting processes: A large sample study. The Annals of Statistics, 10(4): 1100-1120.

Andrienko, G., et al. 2010. Space, time and visual analytics. International Journal of Geographic Information Science, 24(10): 1577-1600.

Arregle, J.-L., Miller, T. L., Hitt, M. A., \& Beamish, P. W. 2013. Do regions matter? An integrated institutional and semiglobalization perspective on the internationalization of MNEs. Strategic Management Journal, 34(8): 910-934.

Békés, G., \& Harasztosi, P. 2013. Agglomeration premium and trading activity of firms. Regional Science and Urban Economics, 43(1): 51-64. the host country, we also conducted a number of supplementary analyses in order to better understand the difference between expansion to new locations and expansion in an existing location (e.g., the formation of multiple subsidiaries in the same city). While our data source is somewhat limited with respect to some of the critical organizational antecedents of same-location vs. different-location investment decisions, our exploratory analyses led to the following observations: the type of initial location (core vs. periphery) is not a significant predictor of repeat investment $(p>0.10)$, nor is the time gap between two subsidiaries $(p>0.10)$. However, the odds of the first two subsidiaries being established in the same city are higher when both subsidiaries are in the same industry, when the second subsidiary is in the retail or wholesale industry, or when the second subsidiary is intended to enter a new line of business. By contrast, the odds of the first two subsidiaries being co-located are lower when the MNE is in the wholesale business, or when the second investment was made to follow customers or partner firms.

${ }^{9}$ We thank the anonymous reviewer for this insight concerning secondary core and proximity alternatives.

Benito, G. R., \& Narula, R. (Eds) 2007. Multinationals on the periphery. New York: Palgrave Macmillan.

Beugelsdijk, S., \& Mudambi, R. 2013. MNEs as border-crossing multi-location enterprises: The role of discontinuities in geographic space. Journal of International Business Studies, 44(5): 413-426.

Bickers, R. 1998. Shanghailanders: The formation and identity of the British settler community in Shanghai 1843-1937. Past \& Present, 1(159): 161-211.

Bitters, B. 2009. Spatial relationship networks: Network theory applied to GIS data. Cartography and Geographic Information Science, 36(1): 81-93.

Blevins, D. P., Moschieri, C., Pinkham, B. C., \& Ragozzino, R. 2016. Institutional changes within the European Union: How global cities and regional integration affect MNE entry decisions. Journal of World Business, 51(2): 319-330.

Blomkvist, K., Kappen, P., \& Zander, I. 2010. Quo vadis? The entry into new technologies in advanced foreign subsidiaries of the multinational enterprise. Journal of International Business Studies, 41(9): 1525-1549.

Bobonis, G. J., \& Shatz, H. J. 2007. Agglomeration, adjustment, and state policies in the location of foreign direct investment in the United States. The Review of Economics and Statistics, 89(1): 30-43.

Boschma, R. 2005. Proximity and innovation: A critical assessment. Regional Studies, 39(1): 61-74.

Bourke, P. 1987. CONREC: A contouring subroutine. Byte: Small Systems Journal, 12(6): 143-150.

Box-Steffensmeier, J. M., \& Zorn, C. J. 2001. Duration models and proportional hazards in political science. American Journal of Political Science, 45(4): 972-988. 
Bu, M., \& Wagner, M. 2016. Racing to the bottom and racing to the top: The crucial role of firm characteristics in foreign direct investment choices. Journal of International Business Studies, advance online publication August 24. doi: 10.1057/s41267016-0013-4.

Buis, M. L. 2010. Stata tip 87: Interpretation of interactions in non-linear models. The Stata Journal, 10(2): 305-308.

Cano-Kollmann, M., Cantwell, J., Hannigan, T. J., Mudambi, R., \& Song, J. 2016. Knowledge connectivity: An agenda for innovation research in international business. Journal of International Business Studies, 47(3): 255-262.

Cantwell, J., \& Brannen, M. Y. 2011. Positioning JIBS as an interdisciplinary journal. Journal of International Business Studies, 42(1): 1-9.

Cantwell, J., Dunning, J. H., \& Lundan, S. M. 2010. An evolutionary approach to understanding international business activity: The co-evolution of MNEs and the institutional environment. Journal of International Business Studies, 41(4): 567-586.

Cantwell, J., \& Mudambi, R. 2005. MNE competence-creating subsidiary mandates. Strategic Management Journal, 26(12): 1109-1128.

Cantwell, J., \& Mudambi, R. 2011. Physical attraction and the geography of knowledge sourcing in multinational enterprises. Global Strategy Journal, 1(3-4): 206-232.

Chan, C. M., Makino, S., \& Isobe, T. 2010. Does subnational region matter? Foreign affiliate performance in the United States and China. Strategic Management Journal, 31(11): 1226-1243.

Chang, S.-J. 1995. International expansion strategy of Japanese firms: Capability building through sequential entry. Academy of Management Journal, 38(2): 383-407.

Chang, S.-J., \& Park, S. 2005. Types of firms generating network externalities and MNCs' co-location decisions. Strategic Management Journal, 26(7): 595-615.

Chang, S.-J., \& Rosenzweig, P. M. 2001. The choice of entry mode in sequential foreign direct investment. Strategic Management Journal, 22(8): 747-776.

Chang, S.-J., \& Xu, D. 2008. Spillovers and competition among foreign and local firms in China. Strategic Management Journal, 29(5): 495-518.

Cheng, S. 2014. From East to West: The evolution of China's FDI preferential policies. Business and Public Administration Studies, 1(1): 60-78.

Cleves, M. 2009. How do I analyze multiple failure-time data using Stata? http://www.stata.com/support/faqs/statistics/ multiple-failure-time-data. Accessed July 18, 2016.

Dana, L. P., Etemad, H., \& Wright, R. W. 2008. Toward a paradigm of symbiotic entrepreneurship. International Journal of Entrepreneurship and Small Business, 5(2): 109-126.

David, P. A. 1985. Clio and the economics of QWERTY. American Economic Review (Papers and Proceedings), 75: 332-337.

Davies, K. 2013. China investment policy: An update. OECD Working Papers on International Investment, 1: 1-75.

Delios, A., \& Henisz, W. 2003. Policy uncertainty and the sequence of entry by Japanese firms, 1980-1998. Journal of International Business Studies, 34(3): 227-241.

Economist Intelligence Unit. 2012. Serve the people: The new landscape of foreign investment into China. http://pages.eiu. com/rs/eiu2/images/EIU_ChinaFDI-Jan2012_Final.pdf. Accessed July 18, 2016.

Ezell, M. E., Land, K. C., \& Cohen, L. E. 2003. Modeling multiple failure time data: A survey of variance-corrected proportional hazards models with empirical applications to arrest data. Sociological Methodology, 33(1): 111-167.

Fiske, A. P. 2004. Relational models theory 2.0. In N. Haslam (Ed.), Relational models theory: A contemporary overview: 3-25. Mahwah, NJ: Lawrence Erlbaum Associates.

Florida, R., \& Kenney, M. 1991. Transplanted organizations: The transfer of Japanese industrial organization to the US. American Sociological Review, 56(3): 381-398.
Gao, G., \& Pan, Y. 2010. The pace of MNEs' sequential entries: Cumulative entry experience and the dynamic process. Journal of International Business Studies, 41(9): 1572-1580.

Goerzen, A., Asmussen, C. G., \& Nielsen, B. B. 2013. Global cities and multinational enterprise location strategy. Journal of International Business Studies, 44(5): 427-450.

Goodman, D. S. 2004. The campaign to "Open up the West": National, provincial-level and local perspectives. The China Quarterly, 178(1): 317-334.

Graul, C. 2016. LeafletR: Interactive Web-Maps Based on the Leaflet JavaScript Library. R-package version 0.4-0, http://cran. r-project.org/package=leafletR. Accessed July 18, 2016.

Guillén, M. F. 2002. Structural inertia, imitation, and foreign expansion: South Korean firms and business groups in China, 1987-1995. Academy of Management Journal, 45(3): 509-525.

Guo, D., Gahegan, M., MacEachren, A. M., \& Zhou, B. 2005. Multivariate analysis and geovisualization with an integrated geographic knowledge discovery approach. Cartography and Geographic Information Science, 32(2): 113-132.

Hair, J. F., Black, W. C., Babin, B. J., \& Anderson, R. E. 2010. Multivariate data analysis: A global perspective. Úpper Saddle River: Pearson Prentice Hall Publishing.

Harzing, A. W., \& Sorge, A. 2003. The relative impact of country of origin and universal contingencies on internationalization strategies and corporate control in multinational enterprises: Worldwide and European perspectives. Organization Studies, 24(2): 187-214.

Head, K., Ries, J., \& Swenson, D. 1995. Agglomeration benefits and location choice: Evidence from Japanese manufacturing investments in the United States. Journal of International Economics, 38(3-4): 223-247.

Henisz, W. J., \& Delios, A. 2001. Uncertainty, imitation, and plant location: Japanese multinational corporations, 1990-1996. Administrative Science Quarterly, 46(3): 443-475.

Hernandez, E. 2014. Finding a home away from home: Effects of immigrants on firms' foreign location choice and performance. Administrative Science Quarterly, 59(1): 73-108.

Jean, R. J. B., Tan, D., \& Sinkovics, R. R. 2011. Ethnic ties, location choice, and firm performance in foreign direct investment: A study of Taiwanese business groups FDI in China. International Business Review, 20(6): 627-635.

Johanson, J., \& Vahlne, J. E. 2009. The Uppsala internationalization process model revisited: From liability of foreignness to liability of outsidership. Journal of International Business Studies, 40(9): 1411-1431.

Kalnins, A., \& Chung, W. 2006. Social capital, geography, and survival: Gujarati immigrant entrepreneurs in the US lodging industry. Management Science, 52(2): 233-247.

Kappen, P. 2011. Competence-creating overlaps and subsidiary technological evolution in the multinational corporation. Research Policy, 40(5): 673-686.

Kim, H. 2003. Ethnic enclave economy in urban China: The Korean immigrants in Yanbian. Ethnic \& Racial Studies, 26(5): 802-828.

Kim, H. 2015. Should birds of a feather flock together? Agglomeration-by-nationality trade-off in foreign markets. Academy of Management Proceedings, 2015(1): 14290.

Kim, H., \& Song, J. 2016. Filling institutional voids in emerging economies: The impact of capital market development and business groups on M\&A deal abandonment. Journal of International Business Studies, advance online publication September 13. doi:10.1057/s41267-016-0025-0.

Klier, T., \& McMillen, D. P. 2008a. Clustering of auto supplier plants in the United States. Journal of Business \& Economic Statistics, 26(4): 460-471.

Klier, T., \& McMillen, D. P. 2008b. Evolving agglomeration in the US auto supplier industry. Journal of Regional Science, 48(1): 245-267.

Kogut, B., \& Chang, S.-J. 1996. Platform investments and volatile exchange rates: Direct investment in the US by 
Japanese electronics companies. The Review of Economics and Statistics, 78(2): 221-231.

Krugman, P. 1991. History and industry location: The case of the manufacturing belt. American Economic Review, 81(2): 80-83.

Laursen, K., Masciarelli, F., \& Prencipe, A. 2012. Trapped or spurred by the home region? The effects of potential social capital on involvement in foreign markets for goods and technology. Journal of International Business Studies, 43(9): 783-807.

Levitt, P. 2004. Transnational ties and incorporation: The case of Dominicans in the United States. In D. G. Gutierrez (Ed.), The Columbia history of Latinos in the United States since 1960: 229-256. New York: Columbia University Press.

Lewicki, R. J., \& Bunker, B. 1996. Developing and maintaining trust in work relationships. In R. Kramer \& T. Tyler (Eds), Trust in organizations: 114-139. Newbury Park, CA: Sage.

Li, Y., Gwon, S., \& Hernandez, E. 2015. Ethnic communities, informal institutions, and foreign location choice. Presented at the 5th Strategy Symposium on Emerging Markets, April 23-24, Rice University.

Li, S., \& Park, S. H. 2006. Determinants of locations of foreign direct investment in China. Management and Organization Review, 2(1): 95-119.

Light, I. 1972. Ethnic enterprise in America. Berkeley: University of California Press.

Light, I. 1983. Cities in world perspective. New York: Macmillan.

Light, I. 2010 Entrepreneurship in a bazaar. Entrepreneurship Conference, April 29, Montpellier, France.

Lin, G. C., \& Zhang, A. Y. 2015. Emerging spaces of neoliberal urbanism in China: Land commodification, municipal finance, and local economic growth in prefecture-level cities. Urban Studies, 52(15): 2774-2798.

Loecher, M., \& Ropkins, K. 2015. RgoogleMaps and loa: Unleashing R graphics power on map tiles. Journal of Statistical Software, 63(4): 1-18.

Lorenzen, M., \& Mudambi, R. 2013. Clusters, connectivity, and catch-up: Bollywood and Bangalore in the global economy. Journal of Economic Geography, 13(3): 501-534.

Luo, Y. 2002. Capability exploitation and building in a foreign market: Implications for multinational enterprises. Organization Science, 13(1): 48-63.

Ma, D. 2008. Economic growth in the lower Yangzi region of China in 1911-1937: A quantitative and historical analysis. Journal of Economic History, 68(2): 355-392.

Ma, X., Tong, T. W., \& Fitza, M. 2013. How much does subnational region matter to foreign subsidiary performance? Evidence from Fortune Global 500 corporations' investment in China. Journal of International Business Studies, 44(1): 66-87.

Manning, S., Sydow, J., \& Windeler, A. 2012. Securing access to lower-cost talent globally: The dynamics of active embedding and field structuration. Regional Studies, 46(9): 1201-1218.

Mariotti, S., Piscitello, L., \& Elia, S. 2010. Spatial agglomeration of multinational enterprises: The role of information externalities and knowledge spillovers. Journal of Economic Geography, 10(4): 519-538.

Martin, X., Mitchell, W., \& Swaminathan, A. 1995. Recreating and extending Japanese automobile buyer-supplier links in North America. Strategic Management Journal, 16(8): 589-619.

McCann, P., \& Mudambi, R. 2005. Analytical differences in the economics of geography: The case of the multinational firm. Environment and Planning A, 37(10): 1857-1876.

Meng, G., Law, J., \& Thompson, M. E. 2010. Small-scale healthrelated indicator acquisition using secondary data spatial interpolation. International Journal of Health Geographics, 9(50): 1-17.

Meyer, K. E., Mudambi, R., \& Narula, R. 2011. Multinational enterprises and local contexts: The opportunities and challenges of multiple embeddedness. Journal of Management Studies, 48(2): 235-252.
Meyer, K. E., \& Nguyen, H. 2005. Foreign investment strategies and sub-national institutions in emerging markets: Evidence from Vietnam. Journal of Management Studies, 42(1): 63-93.

Miller, S. R., Thomas, D. E., Eden, L., \& Hitt, M. 2008. Knee deep in the big muddy: The survival of emerging market firms in developed markets. Management International Review, 48(6): 645-666.

Morgan, G. 1998. Varieties of capitalism and the institutional embeddedness of international economic coordination, 14th EGOS Colloquium, 9-11 June, Maastricht.

Morrison, W. M. 2014. China's economic rise: History, trends, challenges, and implications for the United States. Current Politics and Economics of Northern and Western Asia, 23(4): 461-506.

Mudambi, R. 1998. The role of duration in multinational investment strategies. Journal of International Business Studies, 29(2): 239-261.

Mudambi, R. 2002. Knowledge management in multinational firms. Journal of International Management, 8(1): 1-9.

Mudambi, R. 2008. Location, control, and innovation in knowledge-intensive industries. Journal of Economic Geography, 8(5): 699-725.

Mudambi, R., \& Santangelo, G. D. 2016. From shallow resource pools to emerging clusters: The role of multinational enterprise subsidiaries in peripheral areas. Regional Studies, 50(12): 1965-1979.

Naughton, B. 2007. The Chinese economy: Transitions and growth. Cambridge, MA: MIT Press.

Overman, H. G., Redding, S. J., \& Venables, A. J. 2001. The economic geography of trade production and income: A survey of empirics. CEPR Discussion Paper No. 2978. Available at SSRN: https://ssrn.com/abstract=286595.

Park, S. H., \& Ungson, G. R. 1997. The effect of national culture, organizational complementarity, and economic motivation on joint venture dissolution. Academy of Management Journal, 40(2): 279-307.

Pavlovskaya, M. 2006. Theorizing with GIS: A tool for critical geographies? Environment and Planning A, 38(11): 2003-2020.

Peng, M. W. 2003. Institutional transitions and strategic choices. Academy of Management Review, 28(2): 275-296.

Peng, M. W., Sun, S. L., Pinkham, B., \& Chen, H. 2009. The institution-based view as a third leg for a strategy tripod. Academy of Management Perspectives, 23(3): 63-81.

Peng, M. W., Wang, D. Y., \& Jiang, Y. 2008. An institution-based view of international business strategy: A focus on emerging economies. Journal of International Business Studies, 39(5): 920-936.

Polanyi, K., Arensberg, C. M., \& Pearson, H. W. Eds.. 1957. Trade and market in the early empires: Economies in history and theory (pp. 243-269. Glencoe, IL: Free Press.

Porter, M. E. 1998. Clusters and the new economics of competition. Harvard Business Review, 76(6): 77-90.

Portes, A., \& Sensenbrenner, J. 1993. Embeddedness and immigration: Notes on the social determinants of economic action. American Journal of Sociology, 98(6): 1320-1350.

Prentice, R. L., Williams, B. J., \& Peterson, A. V. 1981. On the regression analysis of multivariate failure time data. Biometrika, 68(2): 373-379.

Rangan, S., \& Sengul, M. 2009. The influence of macro structure on the foreign market performance of transnational firms: The value of IGO connections, export dependence, and immigration links. Administrative Science Quarterly, 54(2): 229-267.

Rezaei, S. 2011. Trust as a coopetitive strategy in a global co-ethnic market: Towards an empirically supported theory. International Journal of Business and Globalisation, 7(3): 265-302.

Ristaino, M. R. 2003. Port of last resort: The diaspora communities of Shanghai. Stanford, CA: Stanford University Press.

Santangelo, G. D. 2009. MNCs and linkages creation: Evidence from a peripheral area. Journal of World Business, 44(2): 192-205. 
Schotter, A., \& Beamish, P. W. 2011. General manager staffing and performance in transitional economy subsidiaries: A subnational analysis. International Studies of Management \& Organization, 41(2): 55-87.

Shi, W. S., Sun, S. L., Pinkham, B. C., \& Peng, M. W. 2014. Domestic alliance network to attract foreign partners: Evidence from international joint ventures in China. Journal of International Business Studies, 45(3): 338-362.

Shin, D. J., Hasse, V. \& Schotter, A. 2016. Multinational enterprises within cultural space and place: Integrating cultural distance and tightness-looseness. Academy of Management Journal, advance online publication May 20. doi:10. 5465/amj.2015.0423.

Silverman, B. W. 1986. Density estimation for statistics and data analysis. New York: Chapman and Hall.

Singer, J. D., \& Willett, J. B. 2003. Applied longitudinal data analysis: Modeling change and event occurrence. New York: Oxford University Press.

Spencer, J. W. 2008. The impact of multinational enterprise strategy on indigenous enterprises: Horizontal spillovers and crowding out in developing countries. Academy of Management Review, 33(2): 341-361.

Tan, D., \& Mahoney, J. 2006. Why a multinational firm chooses expatriates: Integrating resource-based, agency, and transaction costs perspectives. Journal of Management Studies, 43(4): 457-484.

Tan, D., \& Meyer, K. E. 2011. Country-of-origin and industry FDI agglomeration of foreign investors in an emerging economy. Journal of International Business Studies, 42(4): 504-520.

Tan, J., \& Tan, D. 2005. Environment-strategy co-evolution and co-alignment: A staged model of Chinese SOEs under transition. Strategic Management Journal, 26(2): 141-157.

Tong, S. Y. 2005. Ethnic networks in FDI and the impact of institutional development. Review of Development Economics, 9(4): 563-580.

Venables, A. J. 1995. Economic integration and the location of firms. American Economic Review, 85(2): 296-300.

Venables, A. J. 2006. Shifts in economic geography and their causes. Economic Review - Federal Reserve Bank of Kansas. City, 91(4): 61-85.

Waldinger, R. 1995. The "other side" of embeddedness: A case study of the interplay of economy and ethnicity. Ethnic and Racial Studies, 18(3): 555-581.

Waldinger, R., Aldrich, H., \& Ward, R. 1990. Ethnic entrepreneurs: Immigrant business in industrial societies. London: Sage Publications.
Wallerstein, I. 1974. The rise and future demise of the world capitalist system: Concepts for comparative analysis. Comparative Studies in Society and History, 16(4): 387-415.

Wang, X., Fan, G., \& Zhu, H. 2007. Marketization in China: Progress and contribution to growth. In R. Garnaut \& L. Song (Eds), China: Linking markets for growth (pp. 30-44). Canberra, Australia: ANU ePress.

Wang, J., \& Lau, S. S. Y. 2008. Forming foreign enclaves in Shanghai: State action in globalization. Journal of Housing and the Built Environment, 23(2): 103-118.

Wang, F., Zhang, L., Zhang, G., \& Zhang, H. 2014. Mapping and spatial analysis of multiethnic toponyms in Yunnan. China. Cartography and Geographic Information Science, 41(1): 86-99.

Wei, L. J., Lin, D. Y., \& Weissfeld, L. 1989. Regression analysis of multivariate incomplete failure time data by modeling marginal distributions. Journal of the American Statistical Association, 84(408): 1065-1073.

Wiersema, M. F., \& Bowen, H. P. 2009. The use of limited dependent variable techniques in strategy research: Issues and methods. Strategic Management Journal, 30(6): 679-692.

Womack, J. P., Jones, D. T., \& Roos, D. 1990. The machine that changed the world. New York: Simon and Schuster.

Wu, F., \& Webber, K. 2004. The rise of "foreign gated communities" in Beijing: Between economic globalization and local institutions. Cities, 21(3): 203-213.

Zaheer, S. 1995. Overcoming the liability of foreignness. Academy of Management Journal, 38(2): 341-363.

Zhang, L. 2008. Ethnic congregation in a globalizing city: The case of Guangzhou. China. Cities, 25(6): 383-395.

Zhang, T. 2013. Subnational institutional environments within a host country, entry mode choices of multinational corporations, foreign affiliate performance and subsequent expansions of foreign affiliates. Unpublished PhD dissertation, the University of Hong Kong, Pokfulam, Hong Kong, People's Republic of China.

Zhou, X., Li, Q., Zhao, W., \& Cai, H. 2003. Embeddedness and contractual relationships in China's transitional economy. American Sociological Review, 68(1): 75-102.

Zhu, H., Eden, L., Miller, S. R., Thomas, D. E., \& Fields, P. 2012. Host-country location decisions of early movers and latecomers: The role of local density and experiential learning. International Business Review, 21(2): 145-155.

\section{APPENDIX}

We conducted an exploratory analysis of the expansion paths of MNEs. Using the complete sample of MNEs with at least two subsidiaries in China (before case-wise deletion and exclusion of repeat investments in the same prefecture-level city), we collated the locations of each MNE's first, second, and third subsidiaries in a Sankey diagram (Figure A1). To improve the readability of the Sankey diagram, we grouped cores and peripheries by regions (see Table A1). Our regions were adapted from the "macro-regions" commonly used by China scholars (Naughton, 2007). The diagram reveals a very dynamic range of expansion patterns between cores and from the periphery to different cores.

The Sankey diagram shows the locations of MNEs' first, second, and third subsidiaries. Firms with only one entry are not shown. The diagram is based on data from all MNEs with at least two subsidiaries in China $(\mathrm{N}=1,799)$, not the more restricted analytical sample used for hypothesis testing. Notably, our analytical sample excludes repeat investments in a single location. Cores and peripheries are grouped into regions for improved readability (see Table A1). 


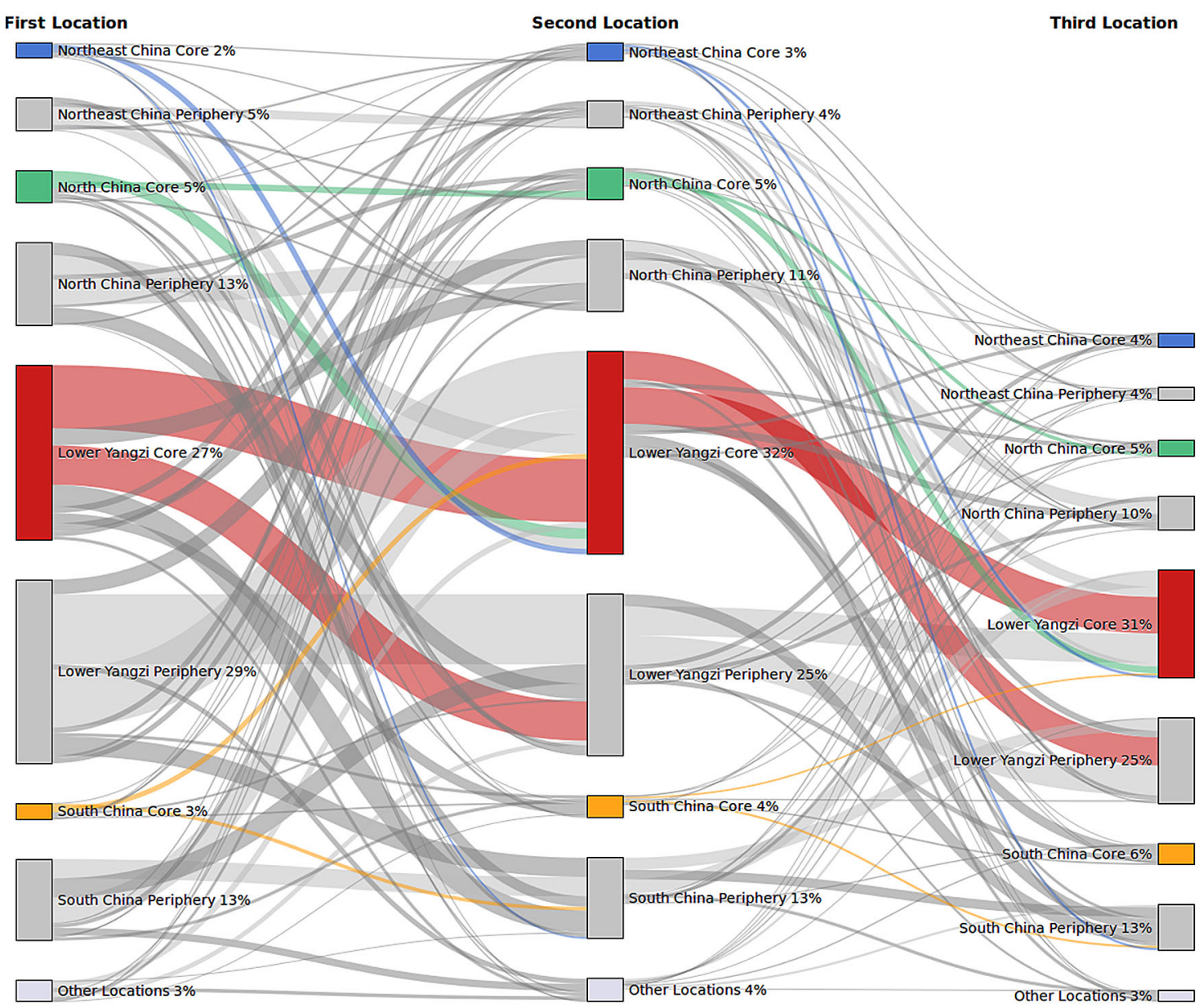

Figure A1 Sankey diagram (within-country expansion paths of MNEs).

Table A1 Composition of macro-regions for Sankey diagram

\begin{tabular}{lll}
\hline Region & Composition (provinces) & Locations of cores (cities) \\
\hline Northeast China & Heilongjiang, Jilin, Liaoning & Dalian (2 cores) \\
North China & Beijing, Hebei, Henan, Shandong, Tianjin & Beijing, Tianjin (2 cores), Qingdao \\
Lower Yangzi & Jiangsu, Shanghai, Zhejiang & Changzhou, Hangzhou, Shanghai, Suzhou (2 cores), Wuxi \\
South China & Fujian, Guangdong, Guangxi, Hainan & Guangzhou (2 cores), Shenzhen (2 cores) \\
Other locations & Anhui, Chongqing, Gansu, Guizhou, Hubei, Hunan, No cores \\
& Inner Mongolia, Jiangxi, Ningxia, Qinghai, Shaanxi, & \\
& Shanxi, Sichuan, Tibet, Xinjiang, Yunnan &
\end{tabular}

\section{ABOUT THE AUTHORS}

Maximilian Stallkamp is a doctoral candidate in General Management and International Business at the Ivey Business School, Western University, Canada. His research interests are multinational enterprise development, location choice, and emerging economies. Max holds an M.A. in Strategy and International Management from the University of St. Gallen, Switzerland.
Brian C Pinkham is an Assistant Professor of International Business at the Ivey Business School, Western University, Canada. His research interests are global strategy, international business, and emerging economies, with a focus on the institution-based view. He has published articles in leading journals such as the Academy of Management Perspectives, Entrepreneurship: Theory \& 
Practice, Journal of International Business Studies, Journal of World Business, and Organizational Dynamics.

Andreas P J Schotter is an Assistant Professor of International Business at the Ivey Business School, Western University, Canada. His research interests are MNE development and subsidiary evolution, the management of the headquarterssubsidiary interface in MNEs, emerging markets, and the role of boundary spanners in global organizations. He has published articles in leading journals such as the Academy of Management Journal, Journal of Management Studies, Journal of International Business Studies, MIT Sloan Management Review and others.

Olha Buchel is a data analyst at SiTechnologyGroup, Inc. in London, Ontario. She specializes in geo-visualization, visual analytics, and human information interaction. She has published articles in information science journals and presented her research at a number of international conferences and workshops.

Open Access This article is distributed under the terms of the Creative Commons Attribution 4.0 International License (http://creativecommons.org/ licenses/by/4.0/), which permits unrestricted use, distribution, and reproduction in any medium, provided you give appropriate credit to the original author(s) and the source, provide a link to the Creative Commons license, and indicate if changes were made. 